\title{
Oral administration of nucleotides in calves: Effects on oxidative status, immune response, and intestinal mucosa development
}

\author{
F. R. Dinardo, ${ }^{1}$ A. Maggiolino, ${ }^{1 *}$ (1) T. Martinello, ${ }^{1}$ G. M. Liuzzi, ${ }^{2}$ G. Elia, ${ }^{1}$ N. Zizzo, ${ }^{1}$ T. Latronico, ${ }^{2}$ \\ F. Mastrangelo, ${ }^{1} \odot$ G. E. Dahl, ${ }^{3} \odot$ and P. De Palo ${ }^{1} \odot$ \\ ${ }^{1}$ Department of Veterinary Medicine, University of Bari A. Moro, 70010 Valenzano, Italy \\ 2Department of Biosciences, Biotechnologies and Biopharmaceutics, University of Bari "Aldo Moro," 70026 Bari, Italy \\ ${ }^{3}$ Department of Animal Sciences, University of Florida, Gainesville 32611
}

\begin{abstract}
The present work aimed to investigate the effects of nucleotide oral administration on oxidative stress biomarkers, immune responses, gut morphology, serum biochemical parameters, and growth performance in calves from birth to $25 \mathrm{~d}$ of life. A total of 40 male Holstein Friesian calves were randomly divided in 2 groups. All the calves were born and reared on the same commercial dairy farm. They were fed the same colostrum, milk replacer, and calf starter. Five grams/head of an additive were orally administered with a syringe directly in the mouth to calves of the nucleotide group (NG). The additive contained $74.12 \mathrm{~g} / 100 \mathrm{~g}$ of nucleic acids from hydrolyzed yeast, and $75.38 \%$ was free nucleotide sodium salt. The other group represented the negative control (CG). At $25 \mathrm{~d}$ of life all of the calves were slaughtered. Calves supplemented with nucleotides had a higher final live weight and improved average daily gain, which was associated with better efficiency of nutrient use. Oral nucleotide administration did not affect IgG absorption efficiency; however, NG calves showed greater duodenum villi length and higher crypt depth compared with CG. Oral nucleotide administration increased the activity of antioxidant enzymes (superoxide dismutase, catalase and glutathione peroxidase) and the antioxidant capacity [ferric reducing antioxidant power and 2,2'-azino-bis (3-ethylbenzothiazoline-6-sulphonic acid) scavenging activity] both in plasma and in liver. An enhanced ability of cells to counter reactive oxygen species- and reactive nitrogen species-mediated damage was also observed in peripheral blood mononuclear cells from NG. The findings highlight the effectiveness of oral nucleotide administration, and potentially dietary
\end{abstract}

Received May 31, 2021.

Accepted January 10, 2022

*Corresponding author: aristide.maggiolino@uniba.it supplementation of nucleotides, in boosting oxidative and immune status in newborn calves.

Key words: nucleotides, oxidative status, calf, immune response

\section{INTRODUCTION}

During the early postnatal period, colostrum confers passive immunity by allowing the transfer of maternal immunoglobulins (McGrath et al., 2016; Zhao et al., 2018). Colostrum plays a key role in calf health beyond passive immunity, as it affects the endocrine system and improves gut function through the absorption of specific components (Hammon et al., 2013). Colostrum is a source of micronutrients (e.g., vitamins, and minerals) and other nonnutrient substances, including cytokines, hydrolytic enzymes, hormones, growth factors, and nucleotides (Michaelidou and Steijns, 2006). Composition and biological functions of colostrum differ markedly when compared with mature milk; thus, the transition from colostrum to milk may have important effects on calf health (Fahey et al., 2020). Generally, mature milk has a lower content of nucleotides than colostrum (Schlimme et al., 2000; Sauer et al., 2011). During lactation, the content of nucleotides in milk further decreases, likely as a consequence of their use for DNA synthesis in the mammary gland (Kim et al., 1999).

Nucleotide requirements are particularly high in stress conditions, such as nutrient deficiencies or starvation, or during a rapid growth phase (Stein and Kil, 2006). Mammals may recover nucleotides through the diet, through either the salvage pathway or by de novo synthesis (Sauer et al., 2011). But the latter pathway is a metabolically costly process; thus, the salvage pathway to recycle dietary nucleotides is more favorable, especially during the growth phase (Abbaslou et al., 2020). Nucleotides are involved in several biological processes including the coding and decoding of genetic information, biosynthetic pathway regulation, 
and chemical energy transfer (Jiao and Kim, 2018). Dietary nucleotides may act as physiological mediators, coenzyme components, and promoters of cell growth and division (Domeneghini et al., 2004; Daneshmand et al., 2017). An effect of nucleotides on intestinal health was reported in several monogastric species by modulating the local immune response, increasing the replication rates of enterocytes, and promoting mucosal remodeling (Jung and Batal, 2012; Amorim et al., 2017). Moreover, nucleotide supplementation in piglet diets seems to affect the gut microbial population, promoting the proliferation of beneficial bacteria such as Bifidobacterium spp. and lactobacilli, and counteracting the enterotoxigenic Escherichia coli strains (Rutz et al., 2006; Sauer et al., 2010). The mechanism whereby oral nucleotide administration may affect the growth performance of calves has not been fully elucidated. The efficacy of oral nucleotide administration on calf growth is poorly reported, and findings are inconclusive. In fact, although Kròl (2011) reported that nucleotides improved calf feed efficiency and weight gain, Górka et al. (2021) observed no effect of nucleotide addition on calf growth.

Immune-enhancing effects of nucleotides previously described in humans and nonruminant animals include lymphocyte stimulation, macrophage activation, and immunoglobulin release (Gil, 2002; Mc Naughton et al., 2007; Sauer et al., 2011). Additionally, the role of nucleotides in inflammatory status and oxidative stress responses were also demonstrated in the same animal models (Salobir et al., 2005; Frankič et al., 2006; Weaver and Kim, 2014). To the best of our knowledge, information regarding the antioxidant and antiinflammatory potential of dietary nucleotides in calves is limited, and findings on immune system effects are contradictory. For example, Mashiko et al. (2009) observed increased IgA and IFN- $\gamma$ levels and peripheral blood mononuclear cell (PBMC) proliferation after supplementation with uridine $5^{\prime}$-monophosphate, whereas others did not find the same effects (Kehoe et al., 2008; Kentler, 2012). Comprehensive studies on the actual effects of dietary nucleotides in calves are lacking. We hypothesized that oral administration of nucleotides would improve body growth, as reported by Kròl (2011), probably throughout variation of the morphological aspects of duodenum villi and crypts. We further hypothesized that specific physiological conditions including oxidative stress and immune challenge would benefit from the oral administration of dietary nucleotides. Thus, the present work investigated whether oral nucleotide administration was effective on oxidative stress biomarkers, immune responses, gut morphology, serum biochemical parameters, and growth performances in calves from birth to $25 \mathrm{~d}$ of life.

\section{MATERIALS AND METHODS}

All animal use and procedures for the study were approved by the Ethical Committee for Animal Welfare of Animals employed in scientific research of the Department of Veterinary Medicine of the University of Bari (approval no. 07/2020).

\section{Animal Housing and Feeding}

Forty male Holstein Friesian calves were divided in 2 groups, with each calf assigned to a group randomly by birth order. The freeware software R. V. Lenth (2006-9) was used to determine the minimum sample size (retrieved 4/12/2019 from http://www.stat.uiowa .edu/ rlenth/Power). The experimental design considered the 2 treatments and the 5 times, and for sample calculation the value of $\alpha$ was set to 0.05 and $\beta$ to 0.20 , for a power of 0.80 . The expected difference was set at 0.15 . The plasma concentration of superoxide dismutase (SOD) and its standard deviation (12.2; Seifzadeh et al., 2021) was the outcome considered for sample size calculation. The sample size obtained was of 17 calves, but we included 20 animals, considering the possibility of exclusion of some of them during the trial. All the calves were born and reared on the same commercial dairy farm (Azienda Montecamplo). Soon after calving, each calf was moved to an individual $1.2 \times 2.4 \mathrm{~m}$ stall. Straw bedding was added at a minimum of $20 \mathrm{~cm}$ depth for each pen. Manure was removed 4 times each week (4 different days) and straw was added 3 times each week (3 different days) or as needed to ensure a dry indoor and outdoor environment. The stalls had the same orientation in the farm area and calves were allocated side by side alternating calves from the 2 groups, so that each calf was between 2 calves of the opposite experimental group, to avoid microenvironmental effects that could potentially affect results. Before calf recruitment, 89 cows were milked within $4 \mathrm{~h}$ after calving on 36 farms in the Apulia region to collect colostrum that was then pooled. All the collected colostrum was stored at $4^{\circ} \mathrm{C}$ until reaching the volume of $480 \mathrm{~L}$ of total collected colostrum. The volume was reached in $24 \mathrm{~h}$, so that the first colostrum collected was stored at refrigeration conditions no more than $24 \mathrm{~h}$. All the colostrum was pooled and stored frozen in 2-L plastic bottles, so the colostrum fed to calves had the same composition. After colostrum pooling, Brix degrees were measured using a refractometer (Pal-Colostrum Pocket refractometer, ATAGO USA Inc.) and a sample was stored at $-20^{\circ} \mathrm{C}$ separately for IgG concentration analysis. The Brix degrees were 25.5 and the IgG concentration was approximatively $85 \mathrm{~g} / \mathrm{L}$. 
All calves received $2 \mathrm{~L}$ of pooled colostrum within $2 \mathrm{~h}$ of birth. Thereafter, calves received $2 \mathrm{~L}$ of the pooled colostrum for the next 5 feedings, every $12 \mathrm{~h}$, at 0700 and $1900 \mathrm{~h}$. Colostrum was thawed in a $50^{\circ} \mathrm{C}$ water bath until a temperature of $38^{\circ} \mathrm{C}$ was reached. If calves did not suckle colostrum, they were fed through a plastic probe placed in the abomasum. After the sixth colostrum feeding, $2 \mathrm{~L}$ of milk replacer was fed through scaled buckets provided with valves and teats every 12 h. Milk replacer (DM 95.5\%, CP 23.5\%, fat 19.1\%, lactose 49.9\%; Elvor Starter 60, Sofivo SAS) was diluted in water at $13 \%$ (130 g of milk powder in water brought up to $1 \mathrm{~L}$ volume) and fed immediately. During the trial all calves consumed the provided amount of milk replacer without refusals. Fresh calf starter (DM 87.40\%, CP 17.95\%, NDF 14.1\%; UniCalf19, Plantamura Carlo Alimenti Zootecnici) was offered ad libitum beginning at $1 \mathrm{~d}$, through a manger and intake was recorded daily. Fresh and clean water was offered free choice daily. The nucleotides group (NG) was orally administered with $5 \mathrm{~g} /$ head of an additive containing hydrolyzed yeast (Ribofeed, Prosol SpA) once daily from birth to $25 \mathrm{~d}$. Nucleotides were mixed with water to obtain a cream, which was then administered directly in the mouth using a large syringe, as described by Maggiolino et al. (2019). Table 1 shows gross and nucleotide composition, analyzed according to the method described by Tan et al. (2021). The dosage used in the present trial was indicated by the manufacturer, according to previous empirical trials. Just before oral administration the additive was suspended in $15 \mathrm{~mL}$ of fresh water. The control group (CG) was orally administered $20 \mathrm{~mL}$ of fresh water/head once daily. Both administration of the additive and of fresh water was carried out using a $20 \mathrm{~mL}$ syringe and it was completed soon before the morning colostrum/milk feeding. All the calves were clinically monitored by a veterinarian. During the trial 8 calves (3 NG and 5 CG calves) showed diarrhea. Three were excluded from the trial (2 from CG and 1 from NG) because they needed antimicrobial therapy, whereas the other 5 had a total recovery from clinical signs after hydration therapy lasting $3 \mathrm{~d}$, and continued to be included in the trial. The whole trial lasted 4 mo, from September 2020 to December 2020.

\section{Blood and Tissue Sampling}

Blood samples were collected from each calf at T0 (soon after birth and before first colostrum feeding), T3 (third day of life and soon before the sixth colostrum feeding, $1800 \mathrm{~h}$ ), T7, T15 (at 7 and $15 \mathrm{~d}$ of life respectively, $1800 \mathrm{~h}$ ), and T25 (slaughter). Blood was drawn from the jugular vein through sterile Vacutainer tubes (Becton Dickinson and Co.). At all the times described above, a 9-mL lithium-heparin and a 9-mL clot activator tube was collected. All of the tubes were centrifuged on the farm and serum and plasma were stored immediately at $-20^{\circ} \mathrm{C}$ until analysis. At $\mathrm{T} 25$ four 9-mL EDTA tubes were collected for PBMC analysis, and they were transported at room temperature to the laboratory no more than $2 \mathrm{~h}$ after sampling. After the T25 blood draw, calves were transported $67 \mathrm{~km}$ (travel time ranging from a minimum of $55 \mathrm{~min}$ to a maximum of $80 \mathrm{~min}$ ) to an abattoir and slaughtered. Soon after evisceration, a 5-cm-long duodenum sample was taken at $20 \mathrm{~cm}$ from the pylorus from each calf and fixed in $10 \%$ buffered formalin. Moreover, a sample of liver $(100 \mathrm{~g})$ was taken and stored at $-80^{\circ} \mathrm{C}$ until analysis. All tissue samples were collected about $12 \mathrm{~h}$ after the last feeding.

\section{Growth Performance}

All calves were weighed at birth (before first colostrum) and at $25 \mathrm{~d}$ of life (slaughter). From these data an ADG was calculated for each calf. In addition, the total amount of milk and starter administered to each calf from birth to $25 \mathrm{~d}$ of life was recorded daily. As the quantity of milk replacer and calf starter intake in each experimental group was not different, all the subsequent parameters were calculated from the combined intake of both feeds. Both milk and starter gross compositions were used to calculate DM, ME, and CP intake of each calf. To determine DM conversion rate, metabolizable energy conversion rate (MECR), and crude protein conversion rate (CPCR), the amount of $\mathrm{DM}, \mathrm{ME}$, and $\mathrm{CP}$ necessary for $1 \mathrm{~kg}$ of live weight gain were estimated, respectively. The calculation of $\mathrm{ME}$ intake was carried out according to Rauba et al. (2019).

\section{Morphometric Measurements of Duodenal Villi and Crypts}

For histological analysis, fragments of duodenum of $17 \mathrm{NG}$ calves and $20 \mathrm{CG}$ calves were collected and fixed

Table 1. Gross and nucleotide chemical composition of the supplement

\begin{tabular}{lc}
\hline Gross chemical composition & $\%$ \\
\hline Moisture & 7.70 \\
Protein & 55.63 \\
Free nucleotides sodium salt $\left(7 \mathrm{H}_{2} \mathrm{O}\right)$ & 55.87 \\
Total nucleic acids & 74.12 \\
Nucleotide composition (total nucleotides $=100 \%)$ & \\
Cytidine monophosphate & 21.50 \\
Uridine monophosphate & 25.71 \\
Adenosine monophosphate & 24.21 \\
Guanosine monophosphate & 28.57 \\
\hline
\end{tabular}


in $10 \%$ formalin for $24 \mathrm{~h}$; they were washed in distilled water, dehydrated through a graded alcohol series, and embedded in paraffin. Serial longitudinal sections (4-5 $\mu \mathrm{m})$ were stained by hematoxylin and eosin (Zitnan et al., 2008). The images of the sections were acquired using an HD camera (DS-Fi2 high-definition color camera, Nikon Corporation) connected to an optical microscope (Nikon Eclipse Ni-U, Nikon Corporation) with a $10 \times$ and $20 \times$ magnification; morphometric analyses were carried out using an interactive image analysis system (NIS Elements BR, Nikon Corporation). At least 10 villous with intact lamina propria of each sample were selected and their height was measured; the crypt depth was measured randomly on 5 fields per slide. Villus height was measured from the tip of the villus to the villus-crypt junction, whereas crypt depth was defined as the depth of the invagination between adjacent villi.

\section{Clinical Biochemical Parameters and Serum IgG Concentration}

Serum clinical biochemical parameters were determined using an automated biochemistry analyzer (CS300B; Dirui) as described by De Palo et al. (2018). The following parameters were assessed: alanine aminotransferase (ALT), aspartate aminotransferase (AST), alkaline phosphatase (ALP), total proteins (TP), and albumin (Alb). Globulins (Glob) were calculated from $\mathrm{TP}$ and Alb parameters. Activities of ALT, AST, and ALP were expressed as U/L, whereas TP, Alb, and Glob concentrations were reported as g/dL. Before beginning each analytical session, the standards furnished in the assay kits were used to calibrate the multiparameter analyzer (Seracal, Gesan Production Kit, Campobello di Mazara). After setting the calibration curve, 2 multiparameter control sera (Seracontrol N and Seracontrol P, Gesan Production Kit, Campobello di Mazara) were used to verify internal accuracy and were considered satisfactory when the measured value deviated by no more than $3.00 \%$ from the manufacturer's declared values.

To determine bovine IgG concentration in serum samples, a commercially available radial immunodiffusion test was performed (Triple J Farm). Briefly, $5 \mu \mathrm{L}$ of each serum sample was transferred in a radial immunodiffusion plate containing anti-bovine IgG antibody within agarose gel. Three standard solutions of bovine serum $(18.0,147.2$, and $280.3 \mathrm{mg}$ of $\mathrm{IgG} / \mathrm{L})$ were provided in the radial immunodiffusion kit and included in each test plate. After a 20-h incubation at room temperature, precipitin ring diameters were measured and plotted on a concentration-diameter best fit line, established using standard sera. Samples were tested in duplicate wells in 2 independent experiments to determine inter- and intraassay coefficients of variation $(\mathbf{C V})$. Inter- and intraassay CV were $\leq 11.7 \%$. Samples with higher CV were retested.

\section{Antioxidant Enzymes and Total Antioxidant Capacity}

Liver samples were homogenized $(1: 10$, wt/vol) in $100 \mathrm{~m} M$ phosphate buffer, $\mathrm{pH} 7.4$ with an electrically driven Teflon pestle. The homogenate was centrifuged at $4^{\circ} \mathrm{C}$ for $20 \mathrm{~min}$ at $7,000 \times g$, and the supernatant was collected to determine the antioxidant enzyme activities and total antioxidant capacity. Plasma was analyzed without dilution.

Superoxide dismutase (EC 1.15.1.1) activity was determined as described by Misra (1985). The enzymatic activity was based on the $50 \%$ inhibition rate of epinephrine autooxidation at $480 \mathrm{~nm}$. Stimulation of epinephrine autoxidation by traces of heavy metals present as contaminants in the reagents or by the other metals under investigation was prevented by adding $10^{-4} M$ EDTA in the buffer to chelate those ions. Activity of SOD in plasma and liver tissue were expressed, respectively, as units per milliliter $(\mathrm{U} / \mathrm{mL})$ and units per milligram $(\mathrm{U} / \mathrm{mg})$ of protein. The plasma intraassay CV were lower than 1.79 and interassay CV were lower than 11.19. The liver intraassay CV were lower than 0.60 and interassay CV were lower than 1.52 . Catalase (CAT, EC 1.11.1.6) activity was evaluated by following the decrease in absorbance of $\mathrm{H}_{2} \mathrm{O}_{2}$ at 240 $\mathrm{nm}$ (Clairborne, 1985). One unit of enzyme activity was defined as the amount of enzyme required to degrade $1 \mu \mathrm{mol}$ of $\mathrm{H}_{2} \mathrm{O}_{2}$ in $60 \mathrm{~s}$. Activity of CAT in liver tissue was expressed as $\mathrm{U} / \mathrm{mg}$ of protein. The intraassay CV were lower than 1.10 and interassay CV were lower than 9.89. Glutathione peroxidase (GPx, EC 1.11.1.9) activity was measured by the method of Gunzler (1986). The reaction measured the rate of reduced glutathione oxidation by tert-butyl hydroperoxide, catalyzed by GPx. Reduced glutathione was maintained at constant concentration by the addition of exogenous glutathione reductase and NADPH, which converted the oxidized glutathione to reduced glutathione. The rate of oxidized glutathione formation was then measured by the change in the absorbance of NADPH at $340 \mathrm{~nm}$. Activity of GPx in plasma and liver tissue were expressed, respectively, as nmol of NADPH oxidized/min per $\mathrm{mL}$ and nmol of NADPH oxidized/min per mg of protein. Protein concentration was determined by Bradford's method using BSA as a standard (Bradford, 1976). The plasma intraassay CV were lower than 1.56 and interassay CV were lower than 12.33. The liver intraassay $\mathrm{CV}$ were lower than 0.56 and interassay $\mathrm{CV}$ were 
lower than 2.64. The ferric reducing antioxidant power (FRAP) assay was used to measure total antioxidant potential according to the method described by Benzie and Strain (1996) with a slight modification. Three milliliters of freshly prepared FRAP reagent $(1 \mathrm{~mL}$ of a 10 $\mathrm{m} M 2,4,6$ tripyridyl-s-triazine solution in $40 \mathrm{~m} M \mathrm{HCl}$ plus $1 \mathrm{~mL}$ of $20 \mathrm{mM} \mathrm{FeCl} 3$ in a $10-\mathrm{mL} \mathrm{H}_{2} \mathrm{O}$ solution and $10 \mathrm{~mL}$ of $300 \mathrm{mM}$ acetate buffer, $\mathrm{pH} 3.6$ ) was incubated at $37^{\circ} \mathrm{C}$ for $40 \mathrm{~min}$ after mixing with $100 \mu \mathrm{L}$ of plasma sample or supernatant. The plasma intraassay CV were lower than 1.70 and interassay CV were lower than 5.29. The liver intraassay CV were lower than 1.20 and interassay CV were lower than 4.21.

The absorbance of the reaction mixture was recorded at $593 \mathrm{~nm}$ and the antioxidant power was expressed as $\mu$ mol Trolox equivalents/mL. 2,2'-Azino-bis [3-ethylbenzothiazoline-6-sulphonic acid] (ABTS) radical scavenging activity was determined according to the procedure previously described by Re et al. (1999) with some modifications. Briefly, ABTS radical cation was produced by mixing $7 \mathrm{mM}$ ABTS stock solution with $2.45 \mathrm{mM}$ potassium persulfate and keeping the mixture in the dark at $25^{\circ} \mathrm{C}$ for 12 to $16 \mathrm{~h}$. The solution was then diluted in PBS to reach an absorbance value of $0.70 \pm 0.02$ at $734 \mathrm{~nm}$. Then, $10 \mu \mathrm{L}$ of plasma sample or supernatant was added to $990 \mu \mathrm{L}$ of diluted ABTS radical cation solution and incubated at $30^{\circ} \mathrm{C}$ for 5 min. The reagent blank was prepared by adding $10 \mu \mathrm{L}$ of PBS instead of the sample. The scavenging of the ABTS radical cation was determined spectrophotometrically at $734 \mathrm{~nm}$. Antioxidant activity was expressed as a percentage inhibition of ABTS radical cation and calculated by the following equation:

$$
\begin{gathered}
\% \text { inhibition }=100 \times\left(\text { Absorbance }_{734}\right. \text { Control } \\
\left.- \text { Absorbance }_{734} \text { Sample }\right) / \text { Absorbance }_{734} \text { Control }
\end{gathered}
$$

Each sample analysis was performed in triplicate. The plasma intraassay CV were lower than 2.23 and interassay CV were lower than 9.30. The liver intraassay $\mathrm{CV}$ were lower than 1.13 and interassay $\mathrm{CV}$ were lower than 2.24 .

\section{PBMC and Monocyte Isolation}

Peripheral blood was used to isolate PBMC using a Ficoll-Hypaque gradient as reported in Latronico et al. (2007). Briefly, $20 \mathrm{~mL}$ of whole blood, diluted 1:1 with cold $0.9 \%$ (wt/vol) sodium chloride solution (0.9\%), was layered on $10 \mathrm{~mL}$ of Histopaque-1077 solution and centrifuged at $400 \times g$ for $35 \mathrm{~min}$ at $20^{\circ} \mathrm{C}$. The white cell rings were recovered, washed twice with PBS, and then pellets were suspended in Iscove's modified Dulbecco's medium (IMDM), without calcium and magnesium (Sigma Aldrich). Cells were counted in a Burker cell counting chamber, and the viability of cells were obtained by Trypan blue dye exclusion (Sigma Aldrich). For the isolation of monocytes, PBMC suspension in IMDM supplemented with $10 \%$ fetal calf serum was plated in 96-well flat-bottom microplates $\left(100 \mu \mathrm{L}, 2 \times 10^{6}\right.$ cells/well). After incubation for 1 $\mathrm{h}$ at $37^{\circ} \mathrm{C}$ in $5 \% \mathrm{CO}_{2}$, nonadherent lymphocytes were collected and adherent cells, represented by monocytes (about $2 \times 10^{5}$ cells/well), were washed several times. Samples of PBMC suspension $\left(100 \mu \mathrm{L}, 2 \times 10^{5}\right.$ cells/ well) were plated in 96-well U-bottom microplates in serum-free medium and treated with concanavalin A (ConA, at final concentration of $5 \mu \mathrm{g} / \mathrm{mL}$ ), LPS (at final concentration of $10 \mu \mathrm{g} / \mathrm{mL}$ ), or hydrogen peroxide $\left(\mathrm{H}_{2} \mathrm{O}_{2}\right.$, at a final concentration of $\left.1 \mathrm{mM}\right)$ and cultured at $37^{\circ} \mathrm{C}$ in $5 \% \mathrm{CO}_{2}$. Nontreated PBMC represented the negative sample. After incubation for $20 \mathrm{~h}$, the plates were centrifuged at $400 \times g$ for $10 \mathrm{~min}$ at $20^{\circ} \mathrm{C}$ in a microplate centrifuge; then, the culture medium was collected, centrifuged at $10,000 \times g$ for $10 \mathrm{~min}$ at $20^{\circ} \mathrm{C}$, and supernatants were stored at $-80^{\circ} \mathrm{C}$ until analysis, whereas cells were subjected to the viability assay.

\section{Proliferation and Viability Assay}

Cell viability or cytotoxicity of PBMC from the different groups of animals was detected using the 3-(4,5-dimethylthiazol-2-yl)-2,5-diphenyl tetrazolium bromide (MTT) assay as reported in Di Bari et al. (2014). This assay is based on the reduction of MTT by the mitochondrial succinate dehydrogenase in viable cells, to a blue formazan product, which can be spectrophotometrically measured by using a microplate reader. This assay was specifically identified to detect cell viability and proliferation since, in contrast to other colorimetric or fluorescent dyes used to detect cell viability in cultured cells, it allows one to distinguish between healthy cells and cells that, though still alive, have lost their vital functions. Briefly, after the removal of culture medium, cells were rinsed with PBS and incubated at $37^{\circ} \mathrm{C}, 5 \% \mathrm{CO}_{2}$ for $2 \mathrm{~h}$ with $0.5 \mathrm{mg} /$ $\mathrm{mL}$ MTT. After centrifugation of the microplates, the reaction was stopped by removing the medium and the formazan crystals in the cells were solubilized with absolute ethanol. The absorbance values at 560 and 690 $\mathrm{nm}$ were recorded by means of a VersaMax Microplate Reader (Molecular Devices). The difference between the absorbance of each sample at 560 and $690 \mathrm{~nm}$ was calculated. Results are expressed as optical density. 


\section{Reactive Oxygen Species and Reactive Nitrogen Species Detection in PBMC and Monocytes}

Detection of intracellular free radicals was performed by loading PBMC $\left(2 \times 10^{5}\right.$ cells/well in 96 -well plates $)$ or monocytes $\left(2 \times 10^{5}\right.$ cells/well in 96 -well plates $)$ with $10 \mu M 2^{\prime}, 7^{\prime}$-dichlorofluorescein diacetate in phenol redfree IMDM at $37^{\circ} \mathrm{C}$ for $30 \mathrm{~min}$ (Latronico et al., 2021), then treated for $90 \mathrm{~min}$ with ConA (at final concentration of $5 \mu \mathrm{g} / \mathrm{mL}$ ), LPS (at final concentration of $10 \mu \mathrm{g} /$ $\mathrm{mL}$ ), or $\mathrm{H}_{2} \mathrm{O}_{2}$ (at a final concentration of $1 \mathrm{mM}$ ). After incubation, the culture medium was removed and cells were rinsed twice with PBS. Cells were resuspended in phenol red-free IMDM and the spectrofluorometric analysis was performed at $485 \mathrm{~nm}$ excitation/525 nm emission. A negative control sample was represented by cells treated in the same experimental conditions with 2',7'-dichlorofluorescein diacetate. Reactive oxygen species (ROS) production was expressed as arbitrary units of photoluminescence intensity.

Total ROS/reactive nitrogen species (RNS) free radical activity in PBMC supernatants were measured by OxiSelect In Vitro ROS/RNS Assay Kit Green Fluorescence (Cell Biolabs Inc.), according to the manufacturer's instructions. This assay is based on the reaction of ROS and RNS species with 2',7'-dichlorodihydrofluorescein, which is rapidly oxidized to the highly fluorescent 2',7'-dichlorodihydrofluorescein. Green fluorescence was read with a VersaMax Microplate Reader (Molecular Devices) at $480 \mathrm{~nm}$ excitation/530 nm emission. The fluorescence of blank samples was subtracted from sample measurements to eliminate background fluorescence. The fluorescence intensity was directly proportional to the total ROS/RNS levels within the sample and was expressed as arbitrary units of photoluminescence intensity.

\section{Statistical Analysis}

Different data sets were considered and subjected to statistical analysis. The growth performance data were subjected to analysis with mixed model according to the following model:

$$
\mathrm{Y}_{\mathrm{ijk}}=\mu+\alpha_{\mathrm{i}}+\mathrm{N}_{\mathrm{j}}+\mathrm{BW}_{\mathrm{ij}}+\varepsilon_{\mathrm{ijk}},
$$

where $Y_{\mathrm{ijk}}$ represents the growth performance dependent variables, $\mu$ is the overall mean, $\alpha_{i}$ is the ith calf random effect $(\mathrm{i}=1, \ldots, 40), \mathrm{N}_{\mathrm{j}}$ is the effect of the jth oral administration treatment $(\mathrm{j}=1,2), \mathrm{BW}_{\mathrm{ij}}$ is the birth weight as covariate, and $\varepsilon_{\mathrm{ijk}}$ is the error term.

Villus length and crypt depth data were subjected to analysis with mixed model according to the following model:

$$
\mathrm{Y}_{\mathrm{ijk}}=\mu+\alpha_{\mathrm{i}}+\mathrm{N}_{\mathrm{j}}+\mathrm{SW}_{\mathrm{ij}}+\varepsilon_{\mathrm{ijk}},
$$

where $Y_{i j k}$ represents the dependent variables, $\mu$ is the overall mean, $\alpha_{i}$ is the the ith calf random effect $(i=1$, $\ldots, 40), \mathrm{N}_{\mathrm{j}}$ is the effect of the jth oral administration treatment $(\mathrm{j}=1,2), \mathrm{SW}_{\mathrm{ij}}$ is the weight at slaughtering as covariate and $\varepsilon_{\mathrm{ijk}}$ is the error term.

The biochemical parameters were subjected to ANOVA according to the General Linear Model (GLM) procedure as reported the following model:

$$
\mathrm{Y}_{\mathrm{ijkl}}=\mu+\alpha_{\mathrm{i}}+\mathrm{N}_{\mathrm{j}}+\mathrm{T}_{\mathrm{k}}+(\mathrm{N} \times \mathrm{T})_{\mathrm{jk}}+\varepsilon_{\mathrm{ijkl}},
$$

where $Y_{\mathrm{ijkl}}$ represents the biochemical dependent variables, $\mu$ is the overall mean, $\alpha_{\mathrm{i}}$ is the ith calf random effect $(\mathrm{i}=1, \ldots, 40), \mathrm{N}_{\mathrm{j}}$ is the effect of the $\mathrm{jth}$ oral administration treatment $(\mathrm{j}=1,2), \mathrm{T}_{\mathrm{k}}$ is the effect of the kth time $(1, \ldots, 5),(\mathrm{N} \times \mathrm{T})_{\mathrm{jk}}$ is the binary interaction effect of $\mathrm{jkth}(1, \ldots, 10)$ treatment $\times$ time, and $\varepsilon_{\mathrm{ijkl}}$ is the error term. A Tukey test was applied to evaluate the differences among means when the effect of time or the binary interaction of treatment $\times$ time was significant.

Liver parameter data were subjected to ANOVA according to the GLM procedure as reported in the following model:

$$
\mathrm{Y}_{\mathrm{ijk}}=\mu+\alpha_{\mathrm{i}}+\mathrm{N}_{\mathrm{j}}+\varepsilon_{\mathrm{ijk}}
$$

where $Y_{\mathrm{ijk}}$ represents the liver parameters as dependent variables, $\mu$ is the overall mean, $\alpha_{i}$ is the ith calf random effect $(i=1, \ldots, 40), N_{j}$ is the effect of the jth oral administration treatment $(\mathrm{j}=1,2)$, and $\varepsilon_{\mathrm{ijk}}$ is the error term.

The ROS level parameter data were subjected to ANOVA according to the GLM procedure as reported in the following model:

$$
\mathrm{Y}_{\mathrm{ijkl}}=\mu+\alpha_{\mathrm{i}}+\mathrm{N}_{\mathrm{j}}+\mathrm{H}_{\mathrm{k}}+(\mathrm{N} \times \mathrm{H})_{\mathrm{jk}}+\varepsilon_{\mathrm{ijkl}},
$$

where $Y_{\mathrm{ijkl}}$ represents the ROS levels as dependent variables, $\mu$ is the overall mean, $\alpha_{\mathrm{i}}$ is the ith calf random effect ( $\mathrm{i}=1, \ldots, 40), \mathrm{N}_{\mathrm{j}}$ is the effect of the jth oral administration treatment $(\mathrm{j}=1,2), \mathrm{H}_{\mathrm{k}}$ is the effect of the kth $\mathrm{H}_{2} \mathrm{O}_{2}$ in vitro stimulation $(\mathrm{k}=1,2),(\mathrm{N} \times \mathrm{H})_{\mathrm{jk}}$ is the binary interaction of oral administration and in vitro stimulation $(\mathrm{jk}=1, \ldots, 4)$, and $\varepsilon_{\mathrm{ijk}}$ is the error term. Pairwise comparison was performed by Bonferroni test.

Cell viability parameter data were subjected to ANOVA according to the GLM procedure as reported in the following model: 


$$
\mathrm{Y}_{\mathrm{ijk} \mathrm{l}}=\mu+\alpha_{\mathrm{i}}+\mathrm{N}_{\mathrm{j}}+\mathrm{V}_{\mathrm{k}}+(\mathrm{N} \times \mathrm{V})_{\mathrm{jk}}+\varepsilon_{\mathrm{ijkl}},
$$

where $Y_{\mathrm{ijkl}}$ represents the cell viability as dependent variables, $\mu$ is the overall mean, $\alpha_{i}$ is the ith calf random effect $(\mathrm{i}=1, \ldots, 40), \mathrm{N}_{\mathrm{j}}$ is the effect of the $\mathrm{jth}$ oral administration treatment $(\mathrm{j}=1,2), \mathrm{V}_{\mathrm{k}}$ is the effect of the kth in vitro stimulation $(\mathrm{k}=1, \ldots, 4),(\mathrm{N}$ $\times \mathrm{V})_{\mathrm{jk}}$ is the binary interaction of oral administration and in vitro stimulation $(\mathrm{jk}=1, \ldots, 8)$, and $\varepsilon_{\mathrm{ijkl}}$ is the error term. Pairwise comparison was performed by Bonferroni test.

Significance was set at $P<0.05$, and the results were expressed as means and mean standard error. All the analysis were performed using SAS software (2011, SAS Institute Inc.).

\section{RESULTS}

\section{Growth Performance}

Growth performance patterns of calves are reported in Table 2. At slaughter, NG showed a higher final BW $(P<0.01)$, compared with CG, although the live weight at birth did not differ. In addition, NG showed higher ADG than CG $(P<0.01)$. Regarding feed efficiency, CPCR and MECR were lower $(P<0.05)$ in NG relative to $\mathrm{CG}$; however, no differences were recorded in DM conversion rate between dietary treatments $(P$ $>0.05)$.

\section{Intestinal Morphology}

The morphometric analyses revealed differences of duodenal villi height and crypt depth in relation to the oral administration of nucleotides. As illustrated in Figure 1, mean values of villi height increased after oral administration of nucleotides (NG) compared with $\mathrm{CG}$ $(P<0.01$; histological images are reported in Figure 2$)$.

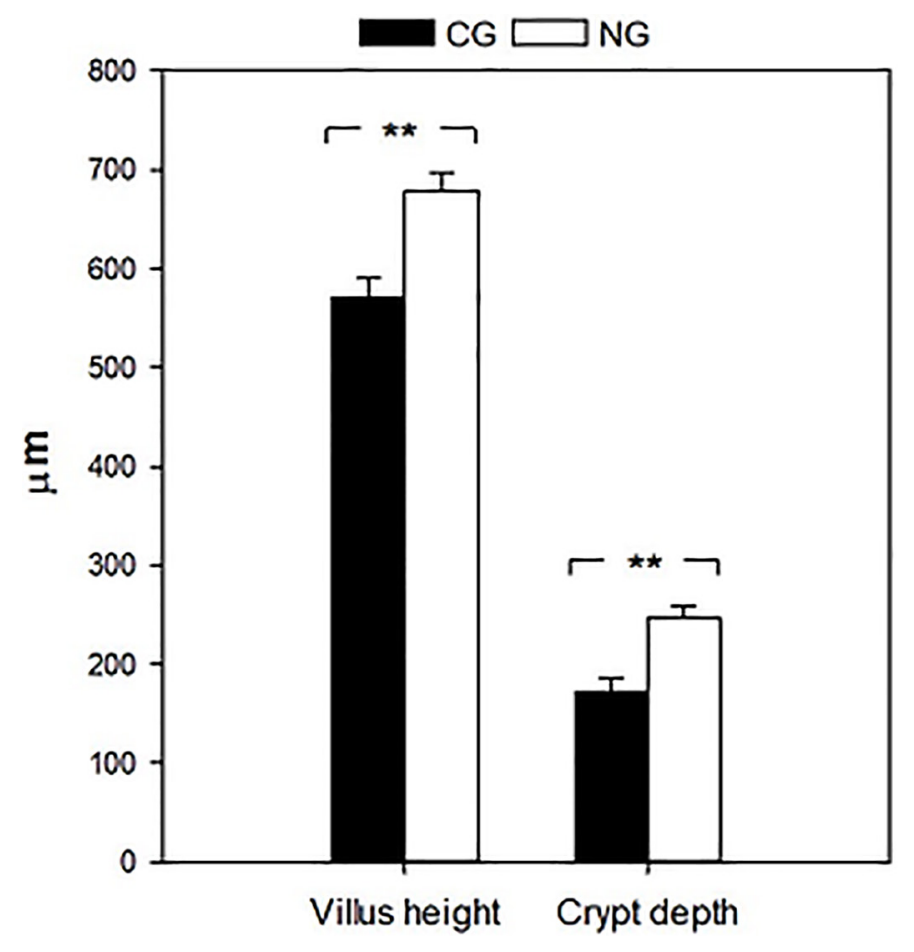

Figure 1. Effects of oral nucleotide administration on duodenum mucosa morphology in control group (CG) or nucleotide group (NG) calves at $25 \mathrm{~d}$ of age. Data are reported as LSM \pm SEM. Significant differences between the 2 groups are indicated with $* *(P<0.01)$.

Similarly, the mean value of crypt depth was greater in NG compared with CG $(P<0.01)$.

\section{Serum Biochemical Profile}

Results for serum chemical and immunological parameters are shown in Figure 3. Serum TP concentration increased from T0 to T3 for CG and from T0 to T7 for NG, decreased thereafter, and was higher at $\mathrm{T} 7$ for NG compared with CG (time $\times$ treatment interaction,

Table 2. Effects of oral administration of nucleotides on growth performance measures in control or supplemented calves for the first $25 \mathrm{~d}$ of life

\begin{tabular}{|c|c|c|c|c|}
\hline \multirow[b]{2}{*}{ Growth performance ${ }^{2}$} & \multicolumn{2}{|c|}{$\operatorname{Diet}^{1}$} & \multirow[b]{2}{*}{ SEM } & \multirow[b]{2}{*}{$P$-value } \\
\hline & $\mathrm{CG}$ & NG & & \\
\hline Live weight at birth $(\mathrm{kg})$ & 42.70 & 43.31 & 1.82 & 0.2963 \\
\hline Live weight at slaughter ( $25 \mathrm{~d}: \mathrm{kg}$ ) & 56.89 & 59.6 & 2.12 & 0.0002 \\
\hline Average starter assumption $(\mathrm{kg})$ & 2.67 & 2.18 & 0.57 & 0.4773 \\
\hline $\mathrm{ADG}(\mathrm{kg} / \mathrm{d})$ & 0.57 & 0.64 & 0.10 & 0.0328 \\
\hline DMCR (kg of feed $/ \mathrm{kg}$ of LWG) & 1.45 & 1.35 & 0.29 & 0.2822 \\
\hline CPCR ( $\mathrm{kg}$ of $\mathrm{CP} / \mathrm{kg}$ of LWG) & 0.33 & 0.30 & 0.09 & 0.0227 \\
\hline MECR (Mcal $/ \mathrm{kg}$ of LWG) & 17.27 & 13.37 & 2.63 & 0.0345 \\
\hline
\end{tabular}

${ }^{1} \mathrm{CG}=$ control group; $\mathrm{NG}=$ nucleotide group.

${ }^{2} \mathrm{DMCR}=$ dry matter conversion rate; $\mathrm{CPCR}=$ crude protein conversion rate; $\mathrm{MECR}=$ metabolizable energy conversion rate; $\mathrm{LWG}=$ live weight gain. 

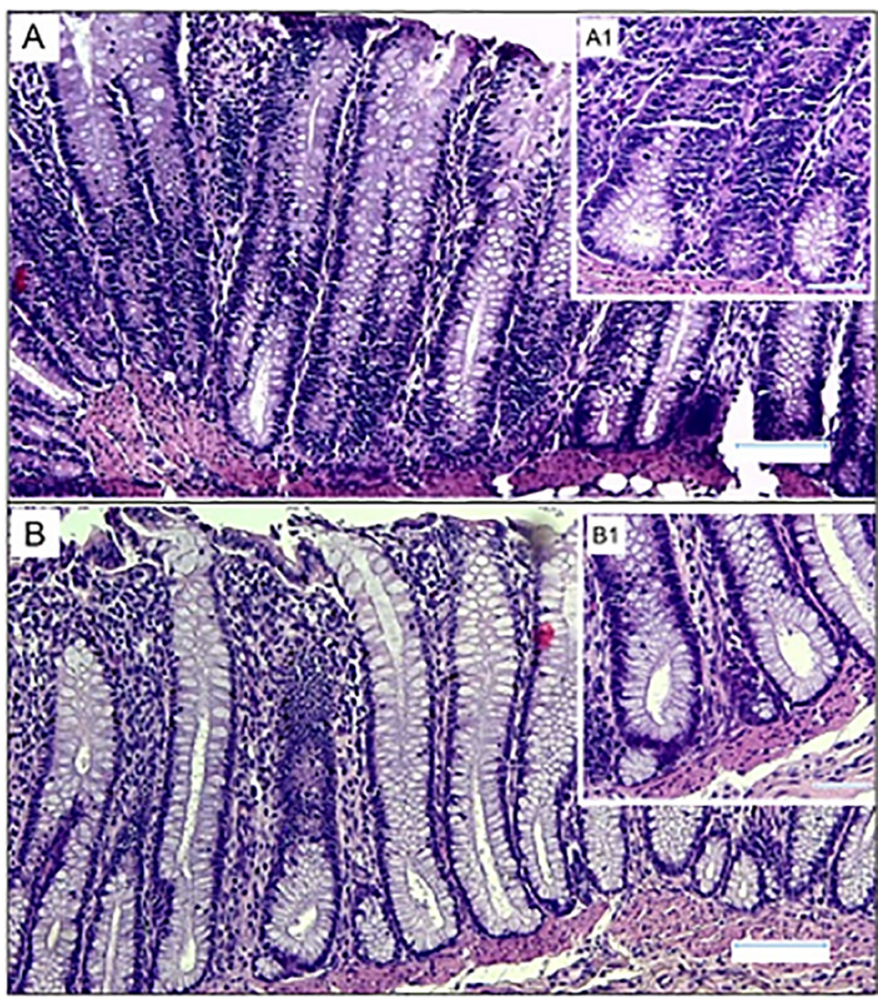

Figure 2. Representative hematoxylin and eosin histology sections of duodenum samples. The panel shows villus and crypts layer of the control group (A) and nucleotide group (B) calves; A1 and B1 illustrate magnification of crypts. $(\mathrm{A}, \mathrm{B})$ bars $=100 \mu \mathrm{m} ;(\mathrm{A} 1, \mathrm{~B} 1)$ bars $=50 \mu \mathrm{m}$

$P<0.001)$. Albumin content remained stable during the feeding trials. Serum Glob concentration increased from $\mathrm{T} 0$ to $\mathrm{T} 3$ for $\mathrm{CG}$ and from $\mathrm{T} 0$ to $\mathrm{T} 7$ for $\mathrm{NG}$, decreased thereafter, and was higher for NG compared with CG at T3 and T7 (time $\times$ treatment interaction, $P<0.001)$. The IgG concentration increased from T0 to T3 in both groups and then remained stable (time, $P<0.001)$; no difference was detected between treatments at any sampling point.

Figure 4 shows results for enzyme activities. The ALP was relatively stable to T15 for CG and then increased, whereas for NG it increased from T0 to T7 and then decreased (time $\times$ treatment interaction, $P<0.001$ ); however, no differences between treatments at any sampling point were detected. The AST activity decreased in CG from T0 to T7 and then remained stable, whereas in the NG group it decreased from T0 to T3, increased from T3 to T15, and then decreased again until T25. Moreover, it was higher in CG compared with NG at T3 and T7 (time $\times$ treatment interaction, $P<0.0001)$. There was effect of treatment, time, and time $\times$ treatment $(P<0.001)$ for ALT concentration.
The ALT concentration decreased with time and was, in general, higher for CG than NG; however, no difference at sampling points were detected between treatments also although time $\times$ treatment interaction was detected, due to apparent ALT increase at T7 for NG.

\section{Oxidative Profile in Plasma and Liver Tissue}

The antioxidant enzyme activity and total antioxidant capacity determined in plasma samples are reported in Figure 5. Plasma SOD activity increased from T0 to $\mathrm{T} 15$ for $\mathrm{NG}$ and remained stable during the trial in CG; moreover, it was higher in NG compared with $\mathrm{CG}$ from T3 to T25 (time $\times$ treatment interaction, $P<$ 0.0001). The plasma GPx activity increased from T0 to T25 for NG and from T0 to T3 for CG; moreover, it was higher in CG at T3 and in NG at T7, T15, and T25 (time $\times$ treatment interaction, $P<0.0001$ ). The total antioxidant capacity of plasma was measured through ABTS and FRAP assays. The FRAP increased from T0 to T3 and from T15 to T25 for NG, the ABTS increased from $\mathrm{T} 0$ to $\mathrm{T} 3$ for $\mathrm{NG}$, then decreased until $\mathrm{T} 7$ and increased again from $\mathrm{T} 7$ to $\mathrm{T} 15$. In contrast, both FRAP and ABTS remained stable during the trial for CG. Moreover, both ABTS and FRAP were higher in NG compared with CG from T3 to T25 (time $\times$ treatment interaction, $P<0.0001)$.

Liver enzyme activities are reported in Figure 6. The SOD, CAT, GPx, FRAP, and ABTS activity increased for NG compared with $\mathrm{CG}$ treatment effect $(P<$ $0.0001)$.

\section{Quantification of ROS/RSN in PBMC and Monocytes}

To gain insight into potential protective effects against oxidative stress, we investigated the accumulation of $\mathrm{ROS}$ within $\mathrm{PBMC}$ under the regular redox state as well as under $\mathrm{H}_{2} \mathrm{O}_{2}$ treatment (Figure 7A). The ROS level produced by untreated PBMC for CG was higher compared with $\mathrm{NG}$, and under $\mathrm{H}_{2} \mathrm{O}_{2}$ stimulation the response was magnified in $\mathrm{CG}$ compared with untreated CG. In contrast, the $\mathrm{H}_{2} \mathrm{O}_{2}$ stimulation did not induce different ROS production levels (binary interaction, $P<0.0001)$.

Unlike PBMC, no difference in ROS production was observed between $\mathrm{CG}$ and $\mathrm{NG}$ untreated monocytes. However, $\mathrm{H}_{2} \mathrm{O}_{2}$ stimulation induced higher ROS production in both $\mathrm{CG}$ and $\mathrm{NG}$ relative to untreated cells $(P<0.05)$.

Other than ROS, RNS are also involved in inflammatory processes, thus we determined total ROS/RNS free radical activity in PBMC supernatants (Figure 8). Higher levels of ROS/RNS were detected in PBMC 

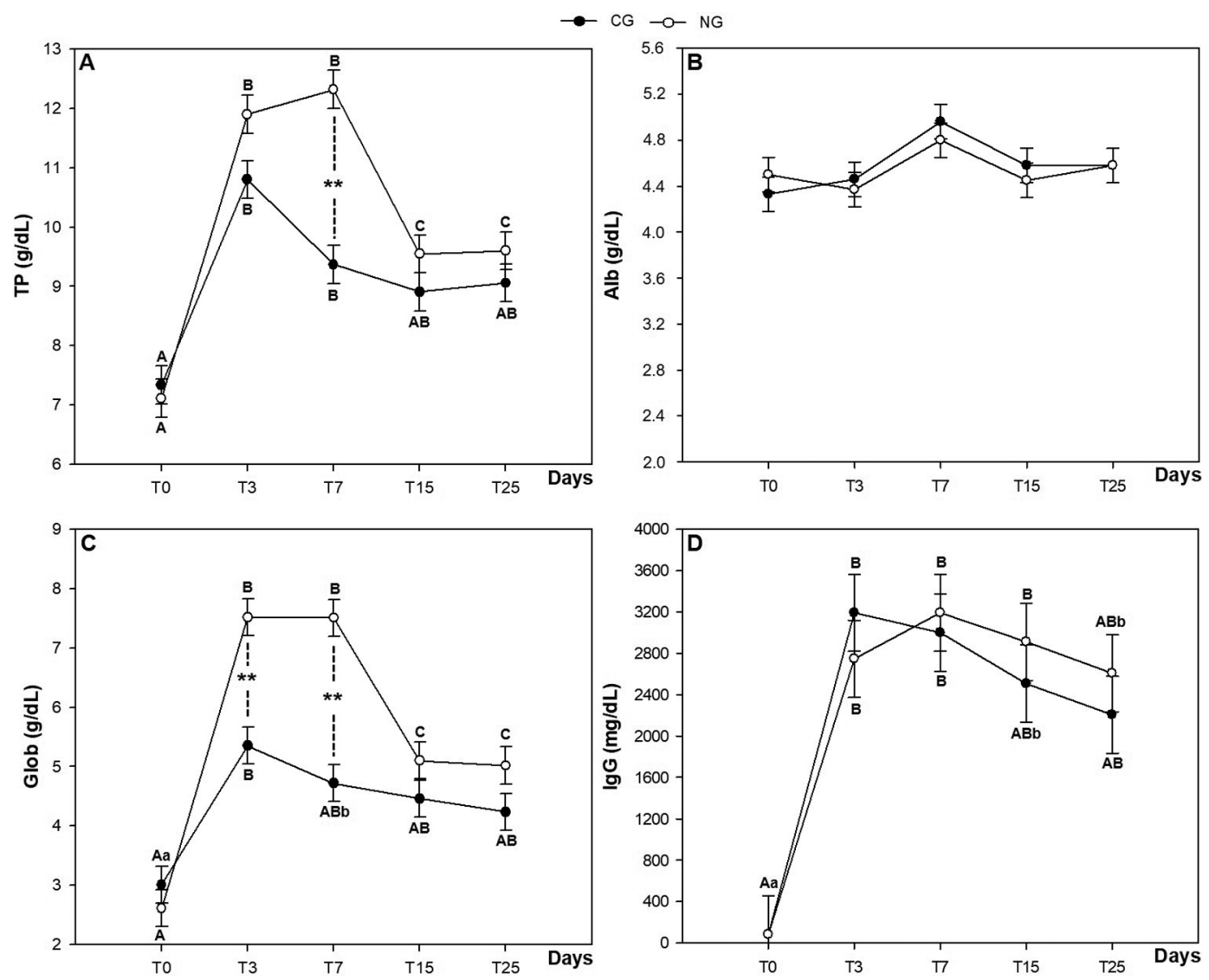

Figure 3. Serum levels of total proteins (TP, panel A), albumin (Alb, panel B), globulins (Glob, panel C), and IgG (panel D) in control group (CG) or nucleotide group (NG) calves during the first $25 \mathrm{~d}$ of life. Data are reported as LSM \pm SEM. Different letters indicate significant differences (A-C: $P<0.01$; a-c: $P<0.05$ ) among sampling days within each group. Significant differences between the 2 groups within days are indicated with $* *(P<0.01)$.

supernatants from CG compared with NG (treatment effect, $P<0.05)$.

\section{PBMC Viability and Proliferation}

Cell viability was determined by the MTT test in PBMC from CG and NG (Figure 9), and it was also tested after $20 \mathrm{~h}$ of in vitro stimulation with ConA, LPS, or $\mathrm{H}_{2} \mathrm{O}_{2}$. In both $\mathrm{CG}$ and $\mathrm{NG}$, only $\mathrm{H}_{2} \mathrm{O}_{2}$ stimulation reduced cell viability. In contrast, no effect was observed after LPS and ConA stimulation (stimulation effect, $P<0.001)$.

\section{DISCUSSION}

During the last decade, the administration of exogenous nucleotides as a feed additive to animal diets has gained the interest of researchers and producers. Nucleotide supplementation has been mainly implemented in monogastric animals and fish (Tie et al.,
2019; Valini et al., 2021), but few research studies have reported effects of nucleotides on ruminants (Abbaslou et al., 2020; Górka et al., 2021). Thus, our trial focused on effects of oral administration of nucleotides on oxidative stress, immune challenge, and morphological changes of calves.

At birth, the transition from the intrauterine hypoxic environment to the relatively hyperoxic external environment likely exposes mammalian neonates to potential oxidative challenge. In fact, cells from newborn animals produce a large amount of ROS in response to the environmental change, leading to neonatal oxidative stress (Mutinati et al., 2014). Routine farm activities, such as weaning, may also induce stress in cattle, putting antioxidant capacity to the test (Jang and Kim, 2019). The balance between oxidative damage and antioxidant capacity is important for maintaining cell homeostasis and physiological activities (Domingues et al., 2016). Our results showed that oral administration of nucleotides significantly decreased ROS levels in PBMC af- 

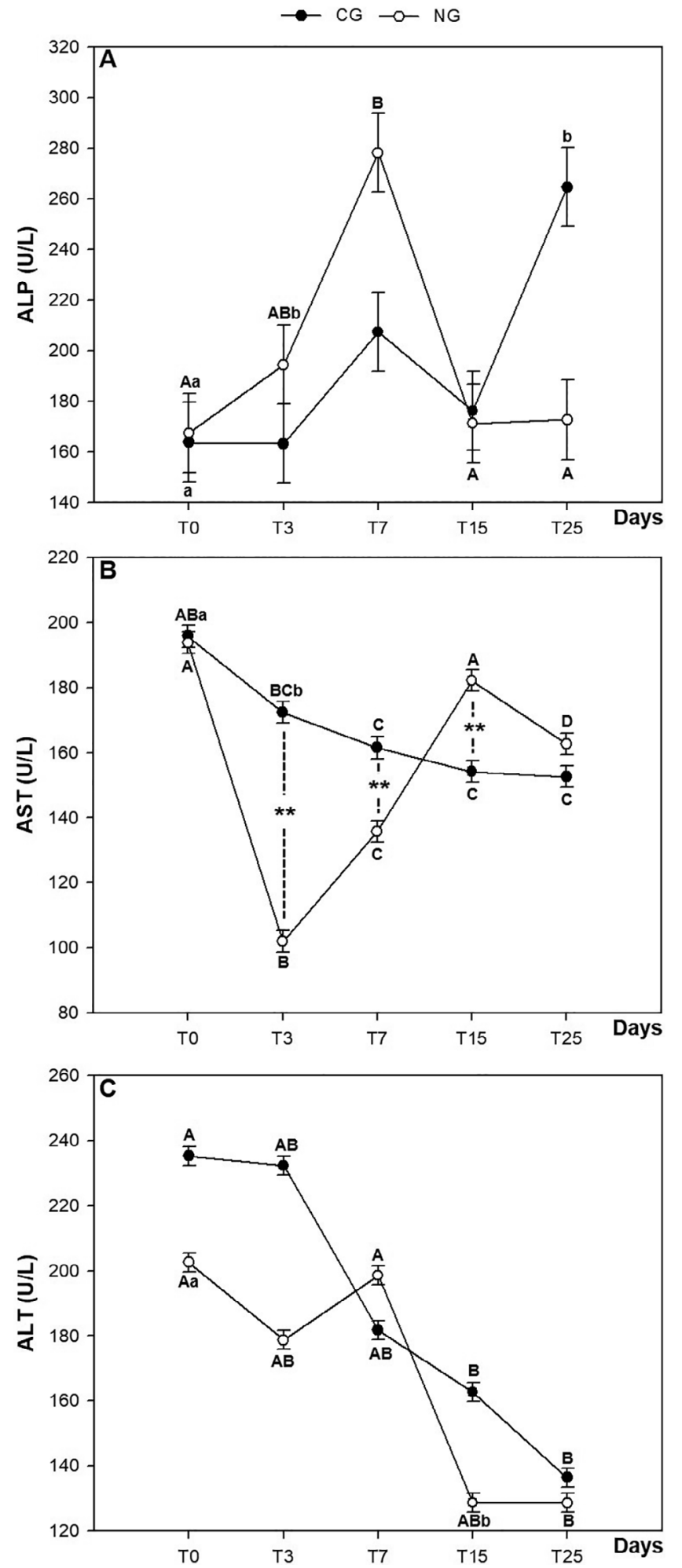

Figure 4. Serum levels of alkaline phosphatase (ALP, panel A), aspartate aminotransferase (AST, panel B), and alanine aminotransferase (ALT, panel C) in control group (CG) or nucleotide group (NG) calves during the first $25 \mathrm{~d}$ of life. Data are reported as LSM \pm SEM. Different letters indicate significant differences (A-D: $P<0.01$; a-c: $P$ $<0.05)$ among sampling days within each group. Significant differences between the 2 groups within days are indicated with $* *(P<0.01)$. ter $25 \mathrm{~d}$ of life in calves, improving potential animal health. In fact, an increase of ROS and RNS combined with poor antioxidant defense may result in cytotoxic events and oxidative stress-mediated macromolecular damage (Celi et al., 2010). Probably, the high ROS levels found in PBMC from CG may be due to an immature antioxidant system against prooxidants, due to the early stage of life. In contrast, oral administration of nucleotides boosted the antioxidative pathways of calves through the increase of antioxidant enzymes, including SOD, CAT, and GPx, in both plasma and liver tissue, allowing the conversion of ROS into harmless products. Moreover, their plasma activity increased by the third day of administration, showing an increased activity in calves fed nucleotides. However, there is no clear mechanism to explain how oral administration of nucleotides acts to enhance the antioxidant enzymatic machinery. In fact, although orally administered directly in the mouth until $25 \mathrm{~d}$ of life, we must consider the possibility that part of nucleotide dose went in the rumen and not directly into the abomasum. For this reason, mechanism of action could be more complex than initially hypothesized. For example, the ROS decrease observed in PBMC from NG may be attributed to the ability of purines to prevent the formation of electron-radical couples from hydroxyl ions by acting as electron donors (Gudkov et al., 2006). Moreover, the nucleotides' ability to protect cells against oxidative stress-related cytotoxicity could be considered (Kaspar et al., 2009; Ihara et al., 2011; Ma, 2013). It has been reported that this mechanism occurred throughout the activity of nitrated guanine derivates, resulting from the combined action of RNS, ROS, and guanylate cyclase, which react with sulfhydryls of sensor proteins, activating an array of defensive genes encoding detoxifying enzymes and antioxidant proteins. Consistent with this proposed mechanism, some authors studying other species including suckling pigs ( $\mathrm{Hu}$ et al., 2018; Weaver and Kim, 2014), chickens (Frankič et al., 2006), and mice (Xu et al., 2013) reported a protective role of dietary nucleotides against the genotoxic effect on DNA induced by high oxidative loads.

Although $\mathrm{H}_{2} \mathrm{O}_{2}$ treatment compromises the intrinsic antioxidant potential of cells by blunting catalase activity and leading to ROS accumulation (Akhter et al., 2019), nucleotides seem to reduce this negative effect. Additionally, we cannot rule out the ability of dietary nucleotides to directly quench ROS/RNS radicals in the extracellular space as detected in PBMC supernatants. Unlike PBMC, monocytes did not show differences in ROS levels according to dietary treatment, even after stimulation with $\mathrm{H}_{2} \mathrm{O}_{2}$, probably due to their ability to engulf microorganisms through an oxygen-dependent system (Yamamoto et al., 2009; Lemke, 2019). 
To evaluate the effect of dietary nucleotides to augment the antioxidant system of calves, we measured the activity of antioxidant enzymes (SOD, CAT, and GPx) and the antioxidant capacity (FRAP and ABTS) in plasma and liver. Our results showed an improvement in enzyme activity and antioxidant capacity due to nucleotide administration, after first administration and consistently during the entire trial. Many authors reported similar results studying dietary nucleotides in other species. Tan et al. (2021) reported increased total antioxidant capacity in gestating sows fed $0.1 \%$ nucleotides and increased GPx activity in their offspring. In rats, Cai et al. (2016) observed a greater ability of the liver to recover from injury through a considerable increase of SOD tissue after nucleotide supplementation. A similar pattern of SOD activity was found in pigs undergoing intrauterine growth retardation (Hu et al., 2018), and in mice under exercise-induced fatigue (Xu et al., 2017). As reported previously, many studies were conducted on dietary nucleotide addition in fish species. Although there are differences in physiology and metabolism that make a direct comparison of our findings impossible with those recorded in fish, most studies suggest that dietary nucleotides ameliorate the oxidative status by reinforcing the antioxidant capacity and upregulating genes encoding for antioxidant enzymes (Tie et al., 2019; de Lima et al., 2020). Indeed, there is a growing body of evidence on the correlation between exogenous nucleotides and high mRNA levels associated with antioxidant enzymes (Salobir et al., 2005; Frankič et al., 2006; Tie et al., 2019).

Overall, the data observed from the serum biochemical profiles in calves of both groups were within the physiological range (Mohri et al., 2007; Yu et al., 2019). However, AST and ALT were subject to high variability, during the $25 \mathrm{~d}$ of life, in both groups. This precluded discrimination of meaningful trends attributable to the dietary treatments or time, though differences
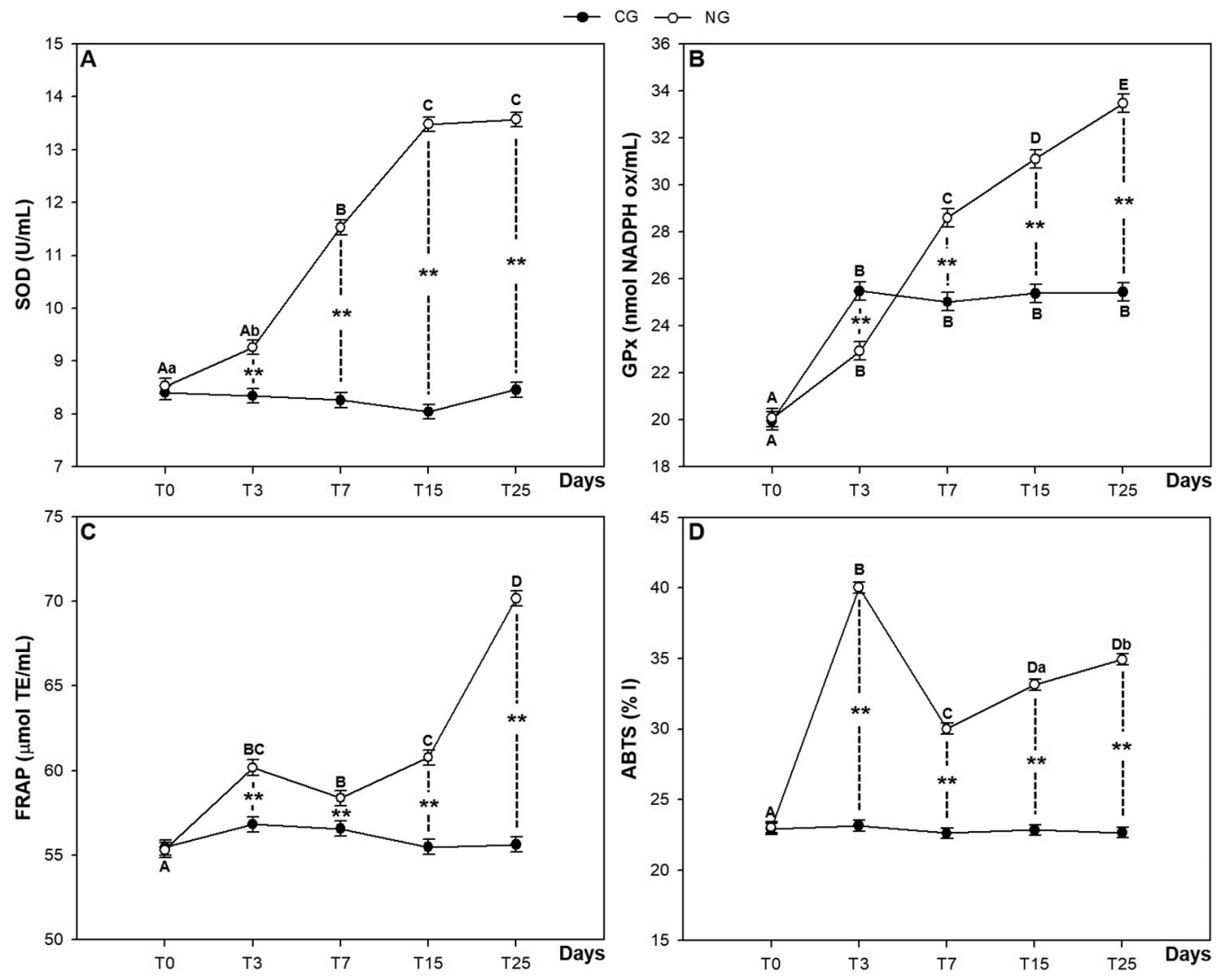

Figure 5. Plasma levels of superoxide dismutase (SOD, panel A), glutathione peroxidase (GPx, panel B), ferric reducing antioxidant power (FRAP, panel C), and 2,2'-azino-bis(3-ethylbenzothiazoline-6-sulphonic acid) scavenging activity (ABTS, panel D) in control group (CG) or nucleotide group (NG) calves during the first $25 \mathrm{~d}$ of life. Data are reported as LSM \pm SEM. Different letters indicate significant differences $($ A-D: $P<0.01 ;$ a-c: $P<0.05)$ among sampling days within each group. Significant differences between the 2 groups within days are indicated with $* *(P<0.01)$. FRAP was expressed as $\mu$ mol Trolox equivalents $(\mathrm{TE}) / \mathrm{mL}$. The ABTS scavenging activity was expressed as a percentage of inhibition (\% I). 


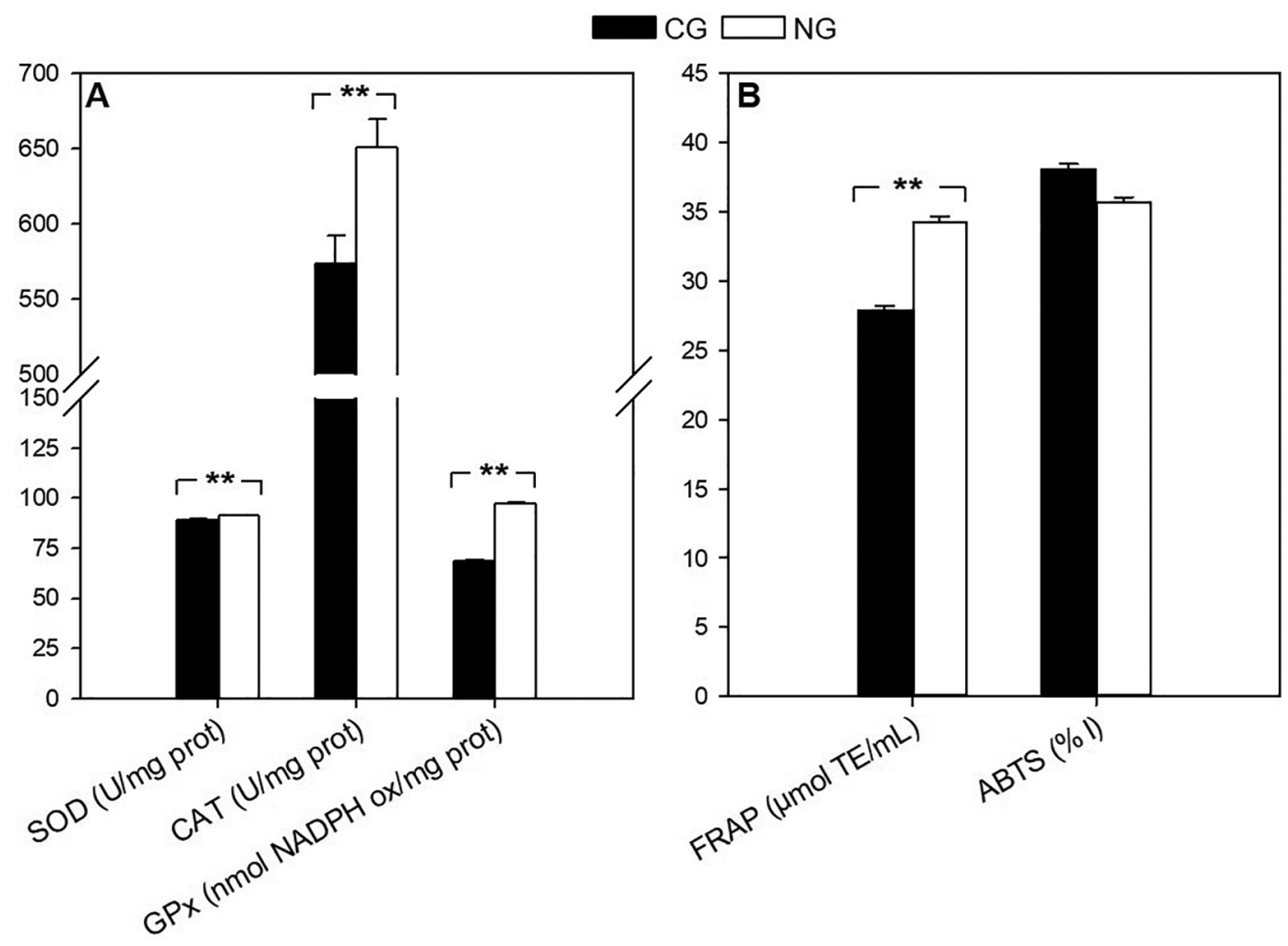

Figure 6. Liver levels of superoxide dismutase (SOD), catalase (CAT), glutathione peroxidase (GPx; panel A), and ferric reducing antioxidant power (FRAP) and 2,2'-azino-bis(3-ethylbenzothiazoline-6-sulphonic acid) scavenging activity (ABTS; panel B) in control group (CG) or nucleotide group (NG) calves at $25 \mathrm{~d}$ of age. Data are reported as LSM \pm SEM. Significant differences between the 2 groups are indicated with ** $(P<0.01)$. FRAP was expressed as $\mu \mathrm{mol}$ Trolox equivalents $(\mathrm{TE}) / \mathrm{mL}$. ABTS scavenging activity was expressed as percentage of inhibition $(\%$ I). Prot = protein.

for AST were recorded between $\mathrm{CG}$ and NG during T3 to T15. The variability of AST and ALT may primarily be explained by the wide diffusion of these enzymes in different tissues and cells, and by the high number of isoenzymes for each enzyme. Indeed, AST is found in cardiac and skeletal muscle, kidney, brain, pancreas, lung, leukocytes, and erythrocytes, whereas ALT is mainly present in the liver and kidneys, with low amounts in cardiac and skeletal muscle. Second, liver enzymes do not always reflect hepatic dysfunction because their release may be due to injured cells as well as to a high rate of development (De Palo et al., 2018; Lehmann-Werman et al., 2018). In fact, AST and ALT activities usually increase concomitantly with animal growth (Schuh et al., 2016). Furthermore, the long half-lives of ALT and AST limits their reliability as markers of liver damage (Kim et al., 2008). Similarly in both groups, serum ALP activity varied widely within the physiological range (166-5,118 U/L; Onomi et al., 2019). Distribution of ALP is wide across different tissues (e.g., liver, bone, intestinal mucosa, kidney, and leukocytes), with a plurality of isoenzymes showing dis- tinct physicochemical properties (Genova et al., 2020). Overall, the increase of ALP activity in newborn calves may be related to colostrum intake or to the production of endogenous enzymes in response to the rapid skeletal growth or to the activity of some organs (De Palo et al., 2018; Onomi et al., 2019). The catalytic role of ALP deals with the breakdown of ingested nucleotides, leading to inorganic phosphate and nucleosides. The latter may be further broken down by nucleosidases to produce purine and pyrimidine bases (Zimmermann, 2001). Once degraded, nucleosides and bases may be incorporated into liver, intestine, and skeletal muscle, although the mechanism whereby they exert their effects on tissue is unclear.

At the gut level, Jang and Kim (2019) reported that dietary nucleotides may improve the intestinal histomorphology in weaned pigs by reducing the mucosal inflammatory response and increasing villi height and crypt depth. It was reported that the villi development also depends on the availability of nucleosides to synthesize DNA, RNA, and ATP molecules, which are essential to enterocyte replication and mucosal 

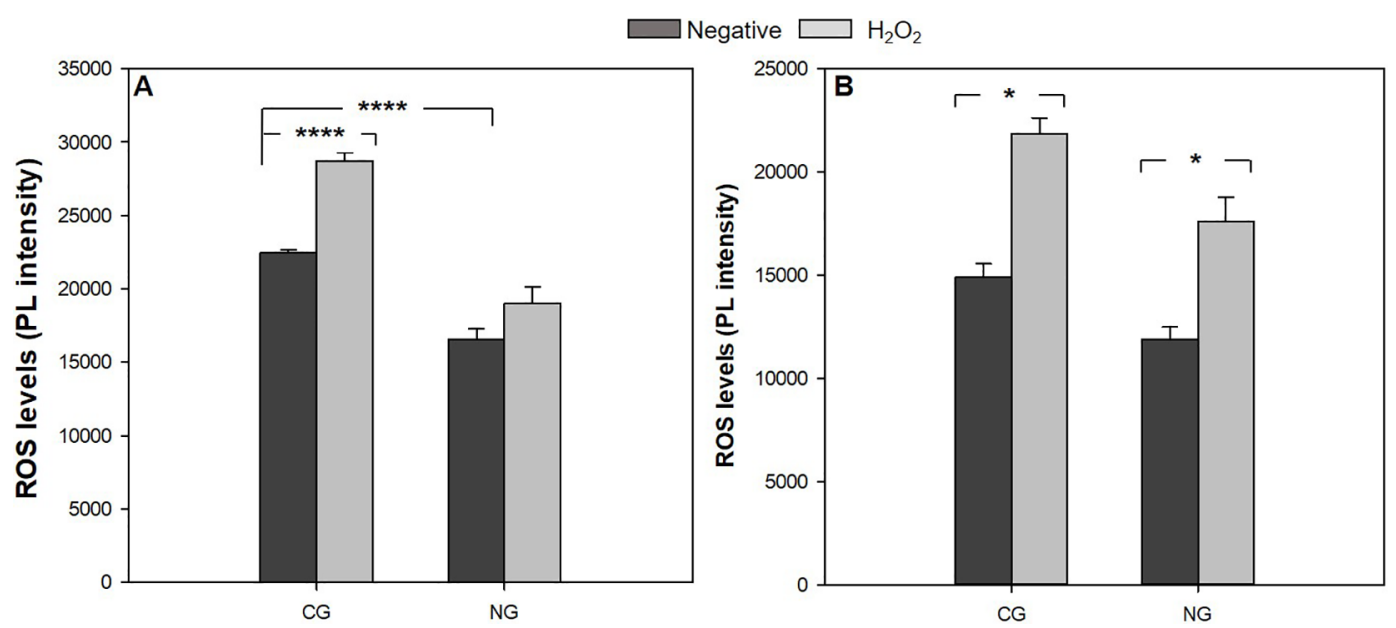

Figure 7. Production of reactive oxygen species (ROS) in peripheral blood mononuclear cells (PBMC) and monocytes from control group (CG) or nucleotide group (NG) calves at $25 \mathrm{~d}$ of age. Histograms represent the ROS production in untreated (negative) and $\mathrm{H}_{2} \mathrm{O}_{2}$-treated $\mathrm{PBMC}$ (panel A) or monocytes (panel B) from the 2 groups of animals. Results are expressed as photoluminescence (PL) intensity units. Data are reported as LSM \pm SEM. Significant differences are indicated with * $(P<0.05)$ and $* * * *(P<0.0001)$.

remodeling (Sato et al., 1999; Jung and Batal, 2012; Amorim et al., 2017). Our results showed that animals that received oral administration of nucleotides showed

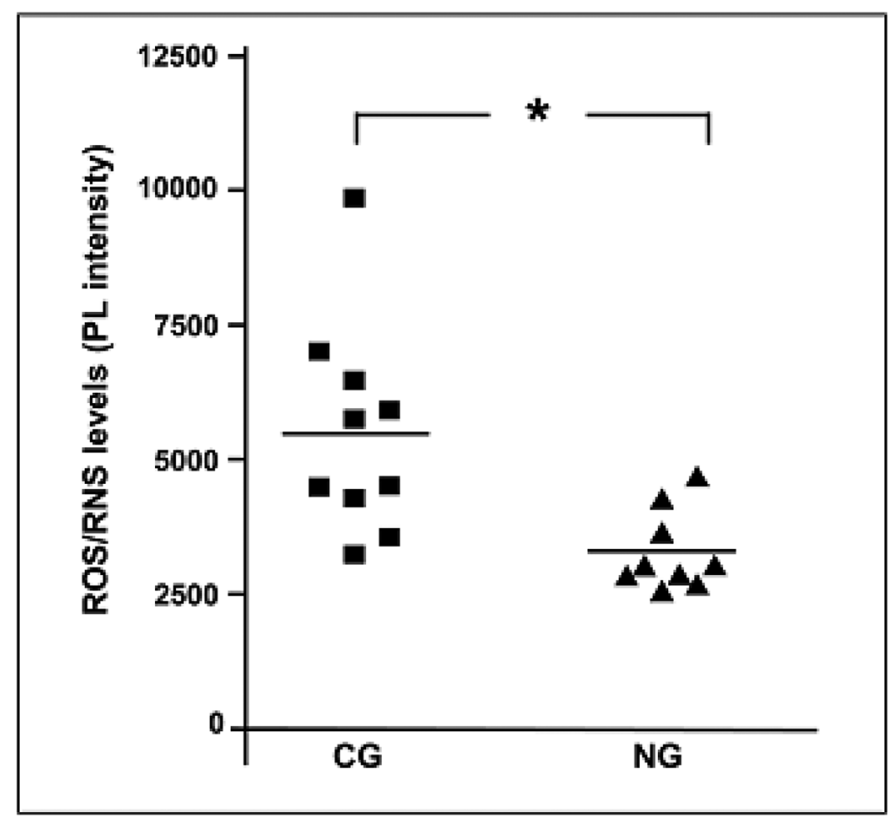

Figure 8. Total reactive oxygen species (ROS)/reactive nitrogen species (RNS) free radical activity in peripheral blood mononuclear cell (PBMC) supernatants from control group (CG) or nucleotide group (NG) calves at $25 \mathrm{~d}$ of age. The scatter plots show the distribution of ROS/RNS production, expressed as photoluminescence (PL) intensity, in supernatants of $\mathrm{PBMC}$ from the 2 groups of animals, collected after $20 \mathrm{~h}$ of incubation at $37^{\circ} \mathrm{C}, 5 \% \mathrm{CO}_{2}$. Horizontal bars indicate the median. Significant differences between the 2 groups are indicated with $*(P<0.05)$. increased villi height and crypt depth, and also improved productive performance, resulting in higher BW at slaughter and greater ADG, CPCR, and MECR. Of course, our experimental conditions are different from that reported for piglets or weaned pigs, considering

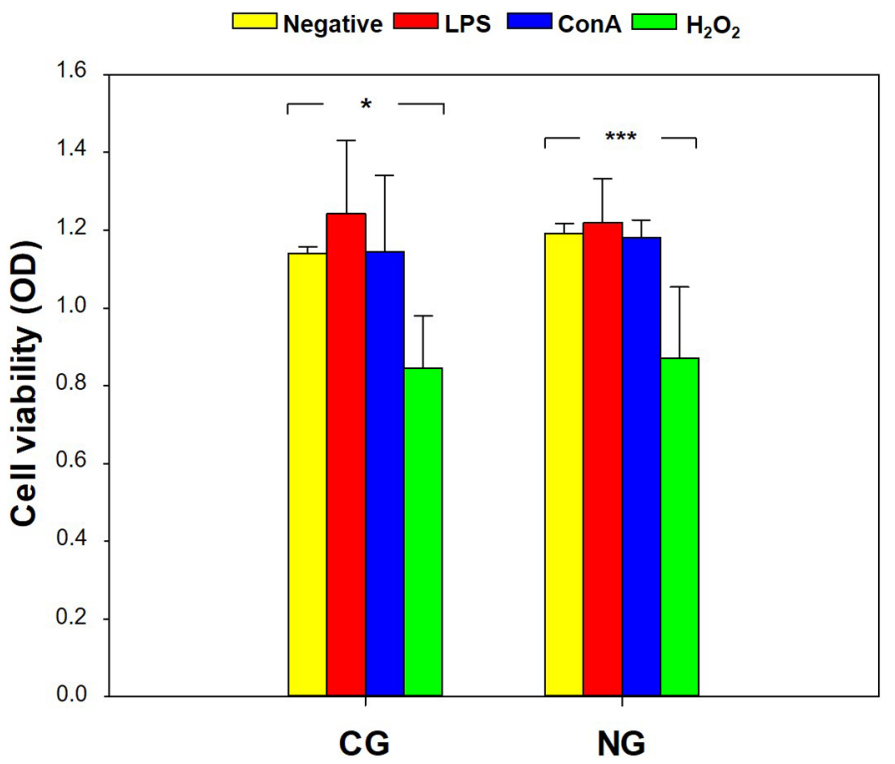

Figure 9. Effect of oral administration of nucleotides on cell viability of peripheral blood mononuclear cells (PBMC) from control group (CG) or nucleotide group (NG) calves at $25 \mathrm{~d}$ of age. Cell viability, expressed as optical density (OD), was detected by the in vitro 3-(4,5-dimethylthiazol-2-yl)-2,5-diphenyl tetrazolium bromide (MTT) test in untreated PBMC (negative) from the 2 groups of animals or PBMC treated for $20 \mathrm{~h}$ at $37^{\circ} \mathrm{C}, 5 \% \mathrm{CO}_{2}$ with LPS, concanavalin A $(\mathrm{ConA})$, or $\mathrm{H}_{2} \mathrm{O}_{2}$. Data are reported as LSM \pm SEM. Significant differences are indicated with $*(P<0.05)$ and ${ }^{* * *}(P<0.001)$. 
that calves are developing ruminants. In fact, although they are functional monogastric, we cannot totally superimpose hypothetical mechanisms of delivery to the intestine and subsequent action to those described for monogastric species. Researchers reported that the greater villi height improved intestinal efficiency of digestive and absorptive processes in chicken (Daneshmand et al., 2017) and weaned pigs (Hernandez et al., 2000). This greater intestinal efficiency can be hypothesized to support the improved growth performance of NG calves. Different results were reported in suckling and postweaning calves by Abbaslou et al. (2020), possibly due to the differences in administration, the different dose used, or both $(2 \mathrm{~g} /$ head, lower than our dose of $5 \mathrm{~g} /$ head). They did not observe any difference in feed efficiency and in final BW of calves fed with addition of nucleotides. Similarly, Kehoe et al. (2008) reported no effect of dietary nucleotides on calf growth performance, but they also used a lower dose, although they proposed that nucleotides would improve enterocyte function, increase surface area due to longer villi, or both. Thus, the better growth performance in the NG calves could be due to a more efficient utilization of nutrients and to greater surface area for nutrient absorption, although our observations are limited to the duodenum and further investigation of the small intestine, especially jejunum, is warranted. In addition to the prominent role of nucleotides in improving the intestinal histomorphology and nutrient absorption, we should also consider the energy gain attributable to the inhibition of de novo synthesis by exogenous nucleotides (Grimble, 1996).

During the dietary treatment, the levels of Alb remained stable, whereas Glob concentrations were subject to substantial variations. Levels of Glob and IgG were mainly affected by their passive immune transfer via colostrum, as shown by the peaks at T3. The efficiency of IgG absorption is influenced by several factors, with the timing of colostrum feeding being the most critical. In fact, calves are capable of immunoglobulin absorption mainly during a brief period up to $24 \mathrm{~h}$ after birth (Halleran et al., 2017). Because the quality and quantity of colostrum administered was the same for all the enrolled animals and no differences in IgG uptake were observed between CG and NG, nucleotide treatment had no effect on passive transfer. Indeed, it is unlikely that the improved intestinal efficiency resulting from the intake of dietary nucleotides occurs quickly enough to facilitate $\operatorname{IgG}$ absorption. Therefore, we conclude that IgG levels are not improved by dietary nucleotide supplementation. However, it is well known that intestinal and immune tissues are closely related because a significant proportion of intestinal cells are of immune origin and intestinal epithelial cells can produce immunomodulatory molecules (Dahan et al., 2007). Considering this, we cannot exclude a potential role of nucleotide administration in newborn calves' immune response (Kletikova et al., 2021). Therefore, oral nucleotide administration may modulate the immune status of calves without directly affecting IgG uptake.

\section{CONCLUSIONS}

Our results clearly indicate that oral nucleotide administration can improve health and growth of calves during the first 25 d of life, with practical implications for the dairy industry. Nucleotide administration improved the activity of antioxidant enzymes (SOD, CAT, and GPx) and the antioxidant capacity (FRAP and ABTS) in calf plasma and liver starting as early as the third day of administration. The enhanced ability of cells to counter ROS- and RNS-mediated damage was also observed in PBMC from calves fed nucleotides. Moreover, nucleotide administration increased the intestinal villi height and crypt depth, with positive consequence on economically important growth parameters (weight gain, ADG, CPCR, and MECR). By stimulating the antioxidant enzymatic machinery and maximizing nutrient intake during weaning, oral nucleotide administration may have the potential to counteract the high prevalence of mortality and morbidity after birth, and to affect long-term cow health and future milk production. The efficacy of dietary nucleotide supplementation was proven in healthy calves under typical farm conditions and are thus easily transferable to the field.

\section{ACKNOWLEDGMENTS}

The authors are grateful to Giovanna Calzaretti, Francesco Giannico, Giuseppe Lopresti, and Rosa Leone for their technical support. Moreover, the authors thank Roberta Greco for her support. The authors express their gratitude to Azienda Agricola Montecamplo and Siciliani SpA (Palo del Colle, Bari, Italy) for allowing us to conduct the trial. The authors declare that this study received funding from Prosol SpA (Madone, Italy) and Agroteam (Torrimpietra, Italy). The funders were not involved in the study design, collection, analysis, interpretation of data, the writing of this article or the decision to submit it for publication. The authors have not stated any conflicts of interest.

\section{REFERENCES}

Abbaslou, Y., E. Mahjoubi, F. Ahmadi, M. R. Farokhzad, D. Zahmatkesh, M. H. Yazdi, and H. Beiranvand. 2020. Performance of 
Holstein calves fed high-solid milk with or without nucleotide. J. Dairy Sci. 103:11490-11495. https://doi.org/10.3168/jds.2020 $-18977$.

Akhter, N., A. Madhoun, H. Arefanian, A. Wilson, S. Kochumon, R. Thomas, S. Shenouda, F. Al-Mulla, R. Ahmad, and S. Sindhu. 2019. Oxidative stress induces expression of the toll-like receptors (TLRs) 2 and 4 in the human peripheral blood mononuclear cells: Implications for metabolic inflammation. Cell. Physiol. Biochem. 53:1-18. https://doi.org/10.33594/000000117.

Amorim, A. B., D. A. Berto, M. A. D. Saleh, G. M. Miassi, and C. Ducatti. 2017. Dietary glutamine, glutamic acid and nucleotides increase the carbon turnover $\left(\delta^{13} \mathrm{C}\right)$ on the intestinal mucosa of weaned piglets. Animal 11:1472-1481. https://doi.org/10.1017/ S1751731117000192.

Benzie, I. F., and J. J. Strain. 1996. The ferric reducing ability of plasma (FRAP) as a measure of "antioxidant power": The FRAP assay. Anal. Biochem. 239:70-76. https://doi.org/10.1006/abio .1996 .0292 .

Bradford, M. M. 1976. A rapid and sensitive method for the quantification of microgram quantities of protein utilizing the principle of protein-dye binding. Anal. Biochem. 72:248-254. https://doi.org/ 10.1016/0003-2697(76)90527-3.

Cai, X., L. Bao, N. Wang, M. Xu, R. Mao, and Y. Li. 2016. Dietary nucleotides supplementation and liver injury in alcohol-treated rats: A metabolomics investigation. Molecules 21:435. https://doi .org/10.3390/molecules21040435.

Celi, P., M. Sullivan, and D. Evans. 2010. The stability of the reactive oxygen metabolites (d-ROMs) and biological antioxidant potential (BAP) tests on stored horse blood. Vet. J. 183:217-218. https:// doi.org/10.1016/j.tvjl.2008.09.018.

Clairborne, A. 1985. Catalase activity. Pages 283-284 in Handbook of Methods for Oxygen Radical Research. R. A. Greenwald, ed. CRC Press.

Dahan, S., F. Roth-Walter, P. Arnaboldi, S. Agarwal, and L. Mayer. 2007. Epithelia: Lymphocyte interactions in the gut. Immunol. Rev. 215:243-253. https://doi.org/10.1111/j.1600-065X.2006 .00484.x.

Daneshmand, A., H. Kermanshahi, M. Danesh Mesgaran, A. J. King, and S. A. Ibrahim. 2017. Effects of pyrimidine nucleosides on growth performance, gut morphology, digestive enzymes, serum biochemical indices and immune response in broiler chickens. Livest. Sci. 204:1-6. https://doi.org/10.1016/j.livsci.2017.08.005.

de Lima, S. A., A. C. O. Pedreira, J. M. A. de Freitas, A. C. S. Dalmaso, R. J. Chiella, F. Meurer, S. Romão, and R. A. Bombardelli. 2020. Diets containing purified nucleotides reduce oxidative stress, interfere with reproduction, and promote growth in Nile tilapia females. Aquaculture 528:735509. https://doi.org/10 .1016/j.aquaculture.2020.735509.

De Palo, P., A. Maggiolino, M. Albenzio, E. Casalino, G. Neglia, G. Centoducati, and A. Tateo. 2018. Survey of biochemical and oxidative profile in donkey foals suckled with one natural and one semi-artificial technique. PLoS One 13:e0198774. https://doi.org/ 10.1371/journal.pone.0198774.

Di Bari, G., E. Gentile, T. Latronico, G. Corriero, A. Fasano, C. N. Marzano, and G. M. Liuzzi. 2014. Comparative analysis of protein profiles of aqueous extracts from marine sponges and assessment of cytotoxicity on different mammalian cell types. Environ. Toxicol. Pharmacol. 38:1007-1015. https://doi.org/10.1016/j.etap.2014.10 .021 .

Domeneghini, C., A. Di Giancamillo, G. Savoini, R. Paratte, V. Bontempo, and V. Dell'Orto. 2004. Structural patterns of swine ileal mucosa following L-glutamine and nucleotide administration during the weaning period. An histochemical and histometrical study. Histol. Histopathol. 19:49-58. https://doi.org/10.14670/HH-19.49.

Domingues, I., R. Oliveira, A. M. V. M. Soares, and M. J. B. Amorim. 2016. Effects of ivermectin on Danio rerio: A multiple endpoint approach: Behaviour, weight and sub-cellular markers. Ecotoxicology 25:491-499. https://doi.org/10.1007/s10646-015-1607-5.

Fahey, M. J., A. J. Fischer, M. A. Steele, and S. L. Greenwood. 2020. Characterization of the colostrum and transition milk proteomes from primiparous and multiparous Holstein dairy cows. J. Dairy Sci. 103:1993-2005. https://doi.org/10.3168/jds.2019-17094.

Frankič, T., T. Pajk, V. Rezar, A. Levart, and J. Salobir. 2006. The role of dietary nucleotides in reduction of DNA damage induced by T-2 toxin and deoxynivalenol in chicken leukocytes. Food Chem. Toxicol. 44:1838-1844. https://doi.org/10.1016/j.fct.2006.06.002.

Genova, J., A. Melo, P. Rupolo, S. Carvalho, L. Costa, and P. Carvalho. 2020. A summary of feed additives, intestinal health and intestinal alkaline phosphatase in piglet nutrition. Czech J. Anim. Sci. 65:281-294. https://doi.org/10.17221/70/2020-CJAS.

Gil, A. 2002. Modulation of the immune response mediated by dietary nucleotides. Eur. J. Clin. Nutr. 56(S3):S1-S4. https://doi.org/10 $.1038 /$ sj.ejcn.1601475.

Górka, P., K. Budzińska, W. Budziński, T. Jankowiak, S. Kehoe, and J. Kański. 2021. Effect of probiotic and nucleotide supplementation in milk replacer on growth performance and fecal bacteria in calves. Livest. Sci. 250:104556. https://doi.org/10.1016/j.livsci .2021.104556.

Grimble, G. K. 1996. Why are dietary nucleotides essential nutrients? Br. J. Nutr. 76:475-478. https://doi.org/10.1079/BJN19960056.

Gudkov, S. V., I. N. Shtarkman, V. S. Smirnova, A. V. Chernikov, and V. I. Bruskov. 2006. Guanosine and inosine display antioxidant activity, protect DNA in vitro from oxidative damage induced by reactive oxygen species, and serve as radioprotectors in mice. Radiat. Res. 165:538-545. https://doi.org/10.1667/RR3552.1.

Gunzler, W. 1986. Glutathione peroxidase. Pages 285-290 in Handbook of Methods for Oxygen Radical Research. R. A. Greenwald, ed. CRC Press.

Halleran, J., H. J. Sylvester, and D. M. Foster. 2017. Apparent efficiency of colostral immunoglobulin G absorption in Holstein heifers. J. Dairy Sci. 100:3282-3286. https://doi.org/10.3168/jds.2016 -11904 .

Hammon, H. M., J. Steinhoff-Wagner, J. Flor, U. Schönhusen, and C. C. Metges. 2013. Lactation biology symposium: Role of colostrum and colostrum components on glucose metabolism in neonatal calves. J. Anim. Sci. 91:685-695. https://doi.org/10.2527/jas.2012 $-5758$.

Hernandez, J., A. Sorbolla, R. Mendoza, and G. Garcia. 2000. Glutamine stimulates the synthesis of immunoglobulin $\operatorname{IgG}$ in infected early weaned pigs. J. Anim. Sci. 78:182.

Hu, L., X. Peng, L. Qin, R. Wang, Z. Fang, Y. Lin, S. Xu, B. Feng, D. Wu, and L. Che. 2018. Dietary nucleotides supplementation during the suckling period improves the antioxidative ability of neonates with intrauterine growth retardation when using a pig model. RSC Advances 8:16152-16160. https://doi.org/10.1039/C8RA00701B.

Ihara, H., T. Sawa, Y. Nakabeppu, and T. Akaike. 2011. Nucleotides function as endogenous chemical sensors for oxidative stress signaling. J. Clin. Biochem. Nutr. 48:33-39. https://doi.org/10.3164/ jcbn.11-003FR.

Jang, K. B., and S. W. Kim. 2019. Supplemental effects of dietary nucleotides on intestinal health and growth performance of newly weaned pigs. J. Anim. Sci. 97:4875-4882. https://doi.org/10.1093/ jas/skz334.

Jiao, Y., and I. H. Kim. 2018. Effects of nucleotide supplementation on growth performance, nutrient digestibility, and immune blood profiles related to foot-and-mouth disease in vaccinated growing pigs. Can. J. Anim. Sci. 99:326-331.

Jung, B., and A. B. Batal. 2012. Effect of dietary nucleotide supplementation on performance and development of the gastrointestinal tract of broilers. Br. Poult. Sci. 53:98-105. https://doi.org/10 $.1080 / 00071668.2012 .659654$

Kaspar, J. W., S. K. Niture, and A. K. Jaiswal. 2009. Nrf2: INrf2 (Keap1) signaling in oxidative stress. Free Radic. Biol. Med. 47:1304-1309. https://doi.org/10.1016/j.freeradbiomed.2009.07 .035 .

Kehoe, S. I., A. J. Heinrichs, C. R. Baumrucker, and D. L. Greger. 2008. Effects of nucleotide supplementation in milk replacer on small intestinal absorptive capacity in dairy calves. J. Dairy Sci. 91:2759-2770. https://doi.org/10.3168/jds.2007-0751. 
Kentler, C. A. 2012. Supplementation of hand-reared neonatal calves with nucleotides and effects on growth, health and immunity. Pages 286-289 in Dairy Research Foundation Current Topics in Dairy Production. S. Garcia, S. Catt, and M. Heward, ed. The University of Sydney.

Kim, S. W., W. L. Hurley, I. K. Han, and R. A. Easter. 1999. Changes in tissue composition associated with mammary gland growth during lactation in sows. J. Anim. Sci. 77:2510-2516. https://doi.org/ 10.2527/1999.7792510x.

Kim, W. R., S. L. Flamm, A. M. Di Bisceglie, and H. C. Bodenheimer. 2008. Serum activity of alanine aminotransferase (ALT) as an indicator of health and disease. Hepatology 47:1363-1370. https:// doi.org/10.1002/hep.22109.

Kletikova, L. V., D. I. Sinelshchikova, and A. N. Martynov. 2021. Prenatal and postnatal correction of the immunobiological status of calves with a drug based on cyclic nucleotides. Pages 1-8 in IOP Conference Series: Earth and Environmental Science. Krasnoyarsk.

Kròl, B. 2011. Effect of mannanoligosaccharides, inulin and yeast nucleotides added to calf milk replacers on rumen microflora, level of serum immunoglobulin and health condition of calves. Electron. J. Pol. Agric. Univ. 14:1-18.

Latronico, T., M. Larocca, S. Milella, A. Fasano, R. Rossano, and G. M. Liuzzi. 2021. Neuroprotective potential of isothiocyanates in an in vitro model of neuroinflammation. Inflammopharmacology 29:561-571. https://doi.org/10.1007/s10787-020-00772-w.

Latronico, T., G. M. Liuzzi, P. Riccio, M. Lichtner, F. Mengoni, C. D'Agostino, V. Vullo, and C. M. Mastroianni. 2007. Antiretroviral therapy inhibits matrix metalloproteinase-9 from blood mononuclear cells of HIV-infected patients. AIDS 21:677-684. https://doi .org/10.1097/QAD.0b013e328018751d.

Lehmann-Werman, R., J. Magenheim, J. Moss, D. Neiman, O. Abraham, S. Piyanzin, H. Zemmour, I. Fox, T. Dor, M. Grompe, G. Landesberg, B.-L. Loza, A. Shaked, K. Olthoff, B. Glaser, R. Shemer, and Y. Dor. 2018. Monitoring liver damage using hepatocyte-specific methylation markers in cell-free circulating DNA. JCI Insight 3:e120687. https://doi.org/10.1172/jci.insight.120687.

Lemke, G. 2019. How macrophages deal with death. Nat. Rev. Immunol. 19:539-549. https://doi.org/10.1038/s41577-019-0167-y.

Ma, Q. 2013. Role of Nrf2 in oxidative stress and toxicity. Annu. Rev. Pharmacol. Toxicol. 53:401-426. https://doi.org/10.1146/annurev -pharmtox-011112-140320.

Maggiolino, A., J. M. Lorenzo, J. Quiñones, M. A. Latorre, F. Blando, G. Centoducati, G. E. Dahl, and P. De Palo. 2019. Effects of dietary supplementation with Pinus taeda hydrolyzed lignin on in vivo performances, in vitro nutrient apparent digestibility, and gas emission in beef steers. Anim. Feed Sci. Technol. 255:114217. https://doi.org/10.1016/j.anifeedsci.2019.114217.

Mashiko, T., S. Nagafuchi, M. Kanbe, Y. Obara, Y. Hagawa, T. Takahashi, and K. Katoh. 2009. Effects of dietary uridine 5'-monophosphate on immune responses in newborn calves. J. Anim. Sci. 87:1042-1047. https://doi.org/10.2527/jas..2008-1004.

McGrath, B. A., P. F. Fox, P. L. McSweeney, and A. L. Kelly. 2016. Composition and properties of bovine colostrum: A review. Dairy Sci. Technol. 96:133-158. https://doi.org/10.1007/s13594-015 $-0258-\mathrm{x}$.

Mc Naughton, L., D. Bentley, and P. Koeppel. 2007. The effects of a nucleotide supplement on the immune and metabolic response to short term, high intensity exercise performance in trained male subjects. J. Sports Med. Phys. Fitness 47:112-118.

Michaelidou, A., and J. Steijns. 2006. Nutritional and technological aspects of minor bioactive components in milk and whey: Growth factors, vitamins and nucleotides. Int. Dairy J. 16:1421-1426. https://doi.org/10.1016/j.idairyj.2006.06.018.

Misra, H. P. 1985. Adrenochrome assay. Pages 237-241 in Handbook of Methods for Oxygen Radical Research. R. A. Greenwald, ed. CRC Press.

Mohri, M., K. Sharifi, and S. Eidi. 2007. Hematology and serum biochemistry of Holstein dairy calves: age related changes and comparison with blood composition in adults. Res. Vet. Sci. 83:30-39. https://doi.org/10.1016/j.rvsc.2006.10.017.
Mutinati, M., M. Pantaleo, M. Roncetti, M. Piccinno, A. Rizzo, and R. L. Sciorsci. 2014. Oxidative stress in neonatology. A review. Reprod. Domest. Anim. 49:7-16. https://doi.org/10.1111/rda.12230.

Onomi, R., K. Hatate, and N. Yamagishi. 2019. Determination of plasma bone-specific alkaline phosphatase isoenzyme activity in Holstein calves using a commercial agarose gel electrophoresis kit. Pol. J. Vet. Sci. 22:789-792. https://doi.org/10.24425/pjvs.2019 .131411 .

Rauba, J., B. J. Heins, H. Chester-Jones, H. L. Diaz, D. Ziegler, J. Linn, and N. Broadwater. 2019. Relationships between protein and energy consumed from milk replacer and starter and calf growth and first-lactation production of Holstein dairy cows. J. Dairy Sci. 102:301-310. https://doi.org/10.3168/jds.2018-15074.

Re, R., N. Pellegrini, A. Proteggente, A. Pannala, M. Yang, and C. Rice-Evans. 1999. Antioxidant activity applying an improved ABTS radical cation decolorization assay. Free Radic. Biol. Med. 26:1231-1237. https://doi.org/10.1016/S0891-5849(98)00315-3.

Rutz, F., E. G. Xavier, J. L. Rech, M. A. Anciuti, and V. F. B. Roll. 2006. Use of NuPro ${ }^{\circledR}$, a rich source of nucleotides, proteins and inositol in swine diets. Pages 121-128 in Nutritional Biotechnology in the Feed and Food Industries. T. P. Lyons, K. A. Jacques, and J. M. Hower, ed. Nottingham University Press.

Salobir, J., V. Rezar, T. Pajk, and A. Levart. 2005. Effect of nucleotide supplementation on lymphocyte DNA damage induced by dietary oxidative stress in pigs. Anim. Sci. 81:135-140. https://doi .org/10.1079/ASC42290135.

Sato, N., T. Nakano, H. Kawakami, and T. Idota. 1999. In vitro and in vivo effects of exogenous nucleotides on the proliferation and maturation of intestinal epithelial cells. J. Nutr. Sci. Vitaminol. (Tokyo) 45:107-118. https://doi.org/10.3177/jnsv.45.107.

Sauer, N., E. Bauer, W. Vahjen, J. Zentek, and R. Mosenthin. 2010. Nucleotides modify growth of selected intestinal bacteria in vitro. Livest. Sci. 133:161-163. https://doi.org/10.1016/j.livsci.2010.06 .053 .

Sauer, N., R. Mosenthin, and E. Bauer. 2011. The role of dietary nucleotides in single-stomached animals. Nutr. Res. Rev. 24:46-59. https://doi.org/10.1017/S0954422410000326.

Schlimme, E., D. Martin, and H. Meisel. 2000. Nucleosides and nucleotides: Natural bioactive substances in milk and colostrum. Br. J. Nutr. 84(S1):S59-S68. https://doi.org/10.1017/ S0007114500002269.

Schuh, S., L. K. F. Muller, L. P. Campos, R. N. Moresco, M. D. Baldissera, S. C. de Oliveira, G. Campigotto, A. S. Da Silva, and D. Paiano. 2016. Effect of supplementation of newborn piglets with spray dry blood plasma on weight gain and serum biochemical variables. Comp. Clin. Pathol. 25:1029-1033. https://doi.org/10 .1007/s00580-016-2302-5.

Seifzadeh, S., J. Seifdavati, H. Abdi Benemar, A. F. Z. M. Salem, and R. Seyed Sharifi. 2021. Evaluation of vitamin C supplementation on growth performance and antioxidant activity of Holstein suckling calves. Iranian J. Anim. Sci. Res. 13:65-75.

Stein, H. H., and D. Y. Kil. 2006. Reduced use of antibiotic growth promoters in diets fed to weanling pigs: Dietary tools, Part 2. Anim. Biotechnol. 17:217-231. https://doi.org/10.1080/ 10495390600957191.

Tan, C., Y. Ji, X. Zhao, Z. Xin, J. Li, S. Huang, Z. Cui, L. Wen, C. Liu, S. W. Kim, J. Deng, and Y. Yin. 2021. Effects of dietary supplementation of nucleotides from late gestation to lactation on the performance and oxidative stress status of sows and their offspring. Anim. Nutr. 7:111-118. https://doi.org/10.1016/j.aninu .2020.10.004.

Tie, H. M., P. Wu, W. D. Jiang, Y. Liu, S. Y. Kuang, Y. Y. Zeng, and L. Feng. 2019. Dietary nucleotides supplementation affect the physicochemical properties, amino acid and fatty acid constituents, apoptosis and antioxidant mechanisms in grass carp (Ctenopharyngodon idellus) muscle. Aquaculture 502:312-325.

Valini, G. A. C., M. S. Duarte, A. A. Calderano, L. M. Teixeira, G. A. Rodrigues, K. M. Fernandes, and G. C. Rocha. 2021. Dietary nucleotide supplementation as an alternative to in-feed antibiotics in weaned piglets. Animal 15:100021. 
Weaver, A. C., and S. W. Kim. 2014. Supplemental nucleotides high in inosine 5 '-monophosphate to improve the growth and health of nursery pigs. J. Anim. Sci. 92:645-651. https://doi.org/10.2527/ jas.2013-6564.

Xu, M., R. Liang, Q. Guo, S. Wang, M. Zhao, Z. Zhang, J. Wang, and Y. Li. 2013. Dietary nucleotides extend the life span in SpragueDawley rats. J. Nutr. Health Aging 17:223-229. https://doi.org/10 .1007/s12603-012-0399-z.

Xu, M., R. Liang, Y. Li, and J. Wang. 2017. Anti-fatigue effects of dietary nucleotides in mice. Food Nutr. Res. 61:1334485. https:// doi.org/10.1080/16546628.2017.1334485.

Yamamoto, T., N. Sakaguchi, M. Hachiya, F. Nakayama, M. Yamakawa, and M. Akashi. 2009. Role of catalase in monocytic differentiation of U937 cells by TPA: Hydrogen peroxide as a second messenger. Leukemia 23:761-769. https://doi.org/10.1038/leu.2008.353.

Yu, K., F. Canalias, D. Solà-Oriol, L. Arroyo, R. Pato, Y. Saco, M. Terré, and A. Bassols. 2019. Age-related serum biochemical reference intervals established for unweaned calves and piglets in the post-weaning period. Front. Vet. Sci. 6:123. https://doi.org/10 3389 /fvets.2019.00123.

Zhao, X. W., Y. X. Qi, D. W. Huang, X. C. Pan, G. L. Cheng, H. L. Zhao, and Y. X. Yang. 2018. Changes in serum metabolites in response to ingested colostrum and milk in neonatal calves, measured by nuclear magnetic resonance-based metabolomics analysis. J. Dairy Sci. 101:7168-7181. https://doi.org/10.3168/jds.2017 $-14287$.

Zimmermann, H. 2001. Ectonucleotidases: Some recent developments and a note on nomenclature. Drug Dev. Res. 52:44-56. https://doi .org/10.1002/ddr.1097.

Zitnan, R., J. Voigt, S. Kuhla, J. Wegner, A. Chudy, U. Schoenhusen, M. Brna, M. Zupcanova, and H. Hagemeister. 2008. Morphology of small intestinal mucosa and intestinal weight change with metabolic type of cattle. Vet. Med. (Praha) 53:525-532. https://doi .org/10.17221/1968-VETMED.

\section{ORCIDS}

A. Maggiolino ( https://orcid.org/0000-0001-7128-8556

F. Mastrangelo @ https://orcid.org/0000-0001-6050-5703

G. E. Dahl $\odot$ https://orcid.org/0000-0002-2182-6317

P. De Palo @ https://orcid.org/0000-0002-5612-1691 